\title{
ESM-SnowMIP: assessing snow models and quantifying snow-related climate feedbacks
}

Gerhard Krinner $^{1}$, Chris Derksen ${ }^{2}$, Richard Essery $^{3}$, Mark Flanner ${ }^{4}$, Stefan Hagemann ${ }^{5}$, Martyn Clark $^{6}$, Alex Hall ${ }^{7}$, Helmut Rott $^{8}$, Claire Brutel-Vuilmet ${ }^{1}$, Hyungjun Kim $^{9}$, Cécile B. Ménard ${ }^{3}$, Lawrence Mudryk ${ }^{2}$, Chad Thackeray ${ }^{7}$, Libo Wang ${ }^{2}$, Gabriele Arduini ${ }^{10}$, Gianpaolo Balsamo ${ }^{10}$, Paul Bartlett ${ }^{2}$, Julia Boike ${ }^{11,12}$, Aaron Boone ${ }^{13}$, Frédérique Chéruy ${ }^{14}$, Jeanne Colin ${ }^{13}$, Matthias Cuntz ${ }^{15}$, Yongjiu Dai ${ }^{16}$, Bertrand Decharme ${ }^{13}$, Jeff Derry ${ }^{17}$, Agnès Ducharne $^{18}$, Emanuel Dutra ${ }^{19}$, Xing Fang ${ }^{20}$, Charles Fierz ${ }^{21}$, Josephine Ghattas ${ }^{22}$, Yeugeniy Gusev ${ }^{23}$, Vanessa Haverd ${ }^{24}$, Anna Kontu ${ }^{25}$, Matthieu Lafaysse ${ }^{26}$, Rachel Law ${ }^{27}$, Dave Lawrence ${ }^{28}$, Weiping Li ${ }^{29}$, Thomas Marke $^{30}$, Danny Marks ${ }^{31}$, Martin Ménégoz ${ }^{1}$, Olga Nasonova ${ }^{23}$, Tomoko Nitta ${ }^{9}$, Masashi Niwano ${ }^{32}$, John Pomeroy ${ }^{20}$, Mark S. Raleigh ${ }^{33}$, Gerd Schaedler ${ }^{34}$, Vladimir Semenov ${ }^{35}$, Tanya G. Smirnova ${ }^{33}$, Tobias Stacke ${ }^{36}$, Ulrich Strasser $^{30}$, Sean Svenson ${ }^{35}$, Dmitry Turkov ${ }^{37}$, Tao Wang ${ }^{38}$, Nander Wever ${ }^{21,39,40}$, Hua Yuan ${ }^{16}$, Wenyan Zhou ${ }^{29}$, and Dan $\mathbf{Z h u}^{41}$

${ }^{1}$ CNRS, Université Grenoble Alpes, Institut de Géosciences de l'Environnement (IGE), 38000 Grenoble, France

${ }^{2}$ Climate Research Division, Environment and Climate Change, Toronto, Canada

${ }^{3}$ School of GeoSciences, University of Edinburgh, Edinburgh EH9 3FF, UK

${ }^{4}$ Department of Climate and Space Sciences and Engineering, University of Michigan, Ann Arbor Michigan 48109, USA

${ }^{5}$ Institute of Coastal Research, Helmholtz-Zentrum Geesthacht, Geesthacht, Germany

${ }^{6}$ Hydrometeorological Applications Program, Research Applications Laboratory, National Center for Atmospheric

Research, Boulder, USA

${ }^{7}$ Department of Atmospheric and Oceanic Sciences, University of California, Los Angeles, Los Angeles, California

${ }^{8}$ ENVEO - Environmental Earth Observation IT GmbH, Innsbruck, Austria

${ }^{9}$ Institute of Industrial Science, the University of Tokyo, Tokyo, Japan

${ }^{10}$ European Centre for Medium-Range Weather Forecasts (ECMWF), Reading, UK

${ }^{11}$ Wegener Institute Helmholtz Centre for Polar and Marine Research, Potsdam, Germany

${ }^{12}$ Department of Geography, Humboldt University of Berlin, Berlin, Germany

${ }^{13}$ CNRM, Université de Toulouse, Météo-France, CNRS, Toulouse, France

${ }^{14}$ LMD-IPSL, Centre National de la Recherche Scientifique, Université Pierre et Marie-Curie, Ecole Normale Supérieure, Ecole Polytechnique, Paris, France

${ }^{15}$ INRA, Université de Lorraine, AgroParisTech, UMR Silva, 54000 Nancy, France

${ }^{16}$ School of Atmospheric Sciences, Sun Yat-sen University, Guangzhou, China

${ }^{17}$ Center for Snow and Avalanche Studies, Siverton, CO, USA

${ }^{18}$ Sorbonne Universités, UMR 7619 METIS, UPMC/CNRS/EPHE, Paris, France

${ }^{19}$ Instituto Dom Luiz, Faculdade de Ciências, Universidade de Lisboa, Lisbon, Portugal

${ }^{20}$ Centre for Hydrology, University of Saskatchewan, Saskatoon, Canada

${ }^{21}$ WSL Institute for Snow and Avalanche Research SLF, Davos, Switzerland

${ }^{22}$ Institut Pierre Simon Laplace (IPSL), UPMC, 75252 Paris, France

${ }^{23}$ Institute of Water Problems, Russian Academy of Sciences, Moscow, Russia

${ }^{24}$ CSIRO Oceans and Atmosphere, Canberra, ACT, Australia

${ }^{25}$ Space and Earth Observation Centre, Finnish Meteorological Institute, 99600 Sodankylä, Finland

${ }^{26}$ Grenoble Alpes, Université de Toulouse, Météo-France, CNRS, CNRM, Centre d'Etudes de la Neige, Grenoble, France

${ }^{27}$ CSIRO Oceans and Atmosphere, Aspendale, Victoria, Australia

${ }^{28}$ National Center for Atmospheric Research, Boulder, CO, USA

${ }^{29}$ National Climate Center, China Meteorological Administration, Beijing, China

${ }^{30}$ Department of Geography, University of Innsbruck, Innsbruck, Austria 
${ }^{31}$ USDA Agricultural Research Service, Boise, ID, USA

${ }^{32}$ Meteorological Research Institute, Japan Meteorological Agency, Tsukuba, Japan

${ }^{33}$ Cooperative Institute for Research in Environmental Science/Earth System Research Laboratory, NOAA, Boulder, CO, USA

${ }^{34}$ Institute of Meteorology and Climate Research, Karlsruhe Institute of Technology, Karlsruhe, Germany

${ }^{35}$ A.M. Obukhov Institute of Atmospheric Physics, Russian Academy of Sciences, Moscow, Russia

${ }^{36}$ Max-Planck-Institut für Meteorologie, Hamburg, Germany

${ }^{37}$ Institute of Geography, Russian Academy of Sciences, Moscow, Russia

${ }^{38}$ Key Laboratory of Alpine Ecology and Biodiversity, Institute of Tibetan Plateau Research, Chinese Academy of Sciences, Beijing, China

${ }^{39}$ Department of Atmospheric and Oceanic Sciences, University of Colorado, Boulder, Colorado, USA

${ }^{40}$ Laboratory of Cryospheric Sciences, School of Architecture and Civil Engineering, Ecole Polytechnique Fédérale de Lausanne, Lausanne, Switzerland

${ }^{41}$ Laboratoire des Sciences du Climat et de l'Environnement, CEA, CNRS, UVSQ, Gif Sur Yvette, France

Correspondence: Gerhard Krinner (gerhard.krinner@cnrs.fr)

Received: 25 June 2018 - Discussion started: 30 July 2018

Revised: 14 November 2018 - Accepted: 19 November 2018 - Published: 10 December 2018

\begin{abstract}
This paper describes ESM-SnowMIP, an international coordinated modelling effort to evaluate current snow schemes, including snow schemes that are included in Earth system models, in a wide variety of settings against local and global observations. The project aims to identify crucial processes and characteristics that need to be improved in snow models in the context of local- and global-scale modelling. A further objective of ESM-SnowMIP is to better quantify snow-related feedbacks in the Earth system. Although it is not part of the sixth phase of the Coupled Model Intercomparison Project (CMIP6), ESM-SnowMIP is tightly linked to the CMIP6-endorsed Land Surface, Snow and Soil Moisture Model Intercomparison (LS3MIP).
\end{abstract}

\section{Introduction}

Snow is a crucial cryospheric component of the climate system. It perennially covers the large continental ice sheets almost entirely and the Earth's sea ice and a large fraction of the Northern Hemisphere ice-free terrestrial areas seasonally. Due to its particular physical properties, snow plays multiple roles in the Earth system. Its high albedo gives rise to the positive snow albedo feedback (Flanner et al., 2011; Qu and Hall, 2014) that amplifies global climate variations and is thought to be a driver of the observed Arctic amplification of the current global warming (Bony et al., 2006; e.g. Chapin III et al., 2005; Pithan and Mauritsen, 2014; Serreze and Barry, 2011) and the observed amplification of global warming at high altitudes (Palazzi et al., 2017; Pepin et al., 2015). Similarly, snow acts as a "fast climate switch" on shorter (weekly and seasonal) timescales, with observed strong coupling between temperature and snow cover (Betts et al., 2014) on re- gional scales. Insulation of underlying soil in winter strongly influences the soil temperature regime and thus the thermal state of permafrost and its carbon balance (Cook et al., 2008; Gouttevin et al., 2012; e.g. Groffman et al., 2001; Park et al., 2015; Vavrus, 2007; Zhang, 2005). In addition, snow influences the ecosystem carbon balance by protecting low vegetation in winter from frost damage (Sturm et al., 2001) and by conditioning the springtime onset of the growing season (Pulliainen et al., 2017). Furthermore, substantial impacts of the presence of snow cover on the atmospheric circulation have been found (Cohen et al., 2012; e.g. Vernekar et al., 2010; Xu and Dirmeyer, 2011); in general, the coupling between snow and atmosphere is strongest during the melting season, and the effect of snow was found to last well into the snow-free season because of its delayed effect on soil humidity (Xu and Dirmeyer, 2011). Linked to its effect on soil humidity, snow has an obvious and profound impact on water availability in snow-dominated regions (Barnett et al., 2005), and large potential economic impacts of snowpack decrease in a warming climate can be expected regionally (e.g. Fyfe et al., 2017; Sturm et al., 2017).

Observed global and (predominantly northern) hemispheric trends of snow cover extent and duration over the recent decades are consistently negative and linked to the observed warming trends (Brown and Mote, 2009; Derksen and Brown, 2012; e.g. Déry and Brown, 2007). Observed snow mass follows similar trends (Cohen et al., 2012; Räisänen, 2008), except in high northern latitudes where warming leads to higher moisture availability (Mote et al., 2018; Räisänen, 2008). Global and hemispheric seasonal snow mass, extent, and snow cover duration are consistently projected to decrease with ongoing warming (e.g. Brutel-Vuilmet et al., 
2013; Collins et al., 2013; Mudryk et al., 2017; Thackeray et al., 2016).

The snow modules included in global coupled climate models which are used for producing these projections come in varying degrees of complexity, from very simple slab models with prescribed physical properties of snow to more sophisticated multilayer models that represent processes such as prognostic albedo, snowpack compaction, liquid water percolation, snow interception, and unloading by vegetation, microstructure in more or less detail. For example, widely varying treatments of the vegetation masking of snow in forest areas are suspected to be a major reason for large intermodel variations of the intensity of the snow albedo feedback (Qu and Hall, 2014; Thackeray et al., 2018). Besides snow modules included in the land surface parameterization packages of large coupled Earth system models (ESMs), there is a large number of other snow models for a range of applications, with their degree of complexity depending on the intended applications (e.g. Magnusson et al., 2015).

Particularly in very cold conditions, it is clear that some important physical processes affecting snow are not captured even by the most detailed physically based snow models, for example the appearance of inverted density gradients due to water vapour fluxes (Domine et al., 2016; Gouttevin et al., 2018). A further important and rarely represented process is wind-blown snow and its sublimation (Pomeroy and Jones, 1996). In addition to these physical processes, accurate representation of vegetation distribution and parameters is also found to be critical for realistic simulation of surface albedo for snow-covered forests (Essery, 2013; Loranty et al., 2014; Wang et al., 2016). Interestingly, however, the behaviour of many snow models can be emulated with multi-physics models (Essery, 2015; Lafaysse et al., 2017). This suggests that in spite of their large variety, "many of them draw on a small number of process parameterizations combined in different configurations and using different parameter values" (Essery et al., 2013). This gives reason to hope that some persistent problems of snow models, and some snow-related problems in ESMs, could in fact be tackled fairly easily, sometimes simply by careful parameter choices. In ESMs, these problems include, for example, the representation of snow masking by vegetation (Essery, 2013; Thackeray et al., 2015), the thermal (Cook et al., 2008; Gouttevin et al., 2012; Slater et al., 2017) and radiative (Flanner et al., 2011; Thackeray et al., 2015) properties of the snowpack, and a resulting persistent large uncertainty concerning the emergent strength of the planetary snow albedo feedback (Flanner et al., 2011; Qu and Hall, 2014). However, it is also clear that even if there is room for improvement in the snow schemes currently used in ESMs, the current knowledge of snow physics also maintains an irreducible uncertainty in snow modelling, even in the most detailed snowpack models currently available (Lafaysse et al., 2017). Additional uncertainty in snow modelling often comes from imperfect meteorological driving data (e.g. Raleigh et al., 2015; Schlögl et al., 2016).
Several model intercomparison exercises focusing on snow, or at least regions that are heavily influenced by the seasonal presence of snow, have been carried out in the past, notably the Programme for Intercomparison of LandSurface Parameterization Schemes (PILPS) Phase 2d (Slater et al., 2001) and Phase 2e (Bowling et al., 2003) as well as SnowMIP Phase 1 (Etchevers et al., 2004) and Phase 2 (Essery et al., 2009; Rutter et al., 2009). These intercomparisons have highlighted some common problems of snow models such as masking of viewable snow by trees and internal processes affecting snow physical properties, particularly during the melting season, leading to potentially large errors in the simulated date of disappearance of the seasonal snow cover. These previous intercomparison exercises have been carried out at small scales, and one important conclusion of the most recent one of these, SnowMIP Phase 2, was that the challenge of evaluating snow models at larger scales, on which they are often applied, needed to be tackled (Essery et al., 2009).

The purpose of this paper is to present a new, already ongoing initiative aiming at evaluating a large range of snow models both at local and large scales, including, but not limited to, land surface models that are part of the ESMs contributing to the current sixth phase of CMIP (Eyring et al., 2016). The initiative presented here, called ESM-SnowMIP, is an extension of LS3MIP (van den Hurk et al., 2016) including site-scale evaluation and process studies as well as complementary, snow-specific, large-scale (global) simulations and analyses.

The overall objectives and rationale of ESM-SnowMIP are presented in the following section. Section 3 describes the planned experiments and analysis strategy, presenting some initial results from the site-scale reference simulations. The discussion in Sect. 4 concerns the expected outcome and impacts of ESM-SnowMIP as well as possible future extensions.

\section{Objectives and rationale}

Common conclusions emerging from previous snow model intercomparisons in PILPS and SnowMIP (Essery et al., 2009; Nijssen et al., 2003; Slater et al., 2001) are that there are large differences between models and that these differences are largest at warmer sites, in warmer winters, and during spring snowmelt. Little insight has been gained into how to reduce this model uncertainty, but it is precisely in the warmer regions that current snow cover is most "at risk" from climate warming (Nolin and Daly, 2006) and where most confidence in projections is required. There has also been a lack of connection between intercomparisons at site scales for which detailed analyses of snow processes are possible and intercomparisons at global scales for which projections of changes in snow cover are required.

The first objective of ESM-SnowMIP is to assess the current state of the art of snow models on spatial scales rang- 
ing from the site scale to global scales. On the site scale, the inclusion of newly developed multi-physics ensemble models (Essery, 2015; Lafaysse et al., 2017) will allow highly controlled experiments to determine the influence of model structure on model performance in snow simulations. The availability of longer-term high-quality observations at a larger range of sites than in previous intercomparison exercises provides the opportunity for a more comprehensive assessment of the current modelling capacity in different climate settings (see Sect. 3.1). Similarly, on the global scale, a wealth of new Northern Hemisphere datasets based on advanced remote-sensing techniques and land surface models driven by reanalysis allows for more meaningful evaluations than has been possible in the past (see Sect. 3.2.1).

In this respect, one particular motivation of ESMSnowMIP is to take advantage of the multi-model CMIP6 setting and at the same time to make particular snow modelling and observational expertise available to climate modelling groups that in the past have not focused their attention on the representation of snow in their coupled models. CMIP6 provides the opportunity to evaluate the representation of the historical evolution of seasonal snow in global simulations with varying degrees of freedom, ranging, for a given model, from global coupled ocean-atmosphere simulations to atmosphere-only (AMIP) climate simulations with prescribed oceanic boundary conditions (Gates, 1992), to land-surface-only simulations (LMIP) forced by observationally based meteorological data (van den Hurk et al., 2016). Combining the evaluation of these global-scale simulations with the detailed process-based assessment at the site scale provides an opportunity for substantial progress in the representation of snow, particularly in Earth system models that have not been evaluated in detail with respect to their snow parameterizations. Concerning this first major objective of model evaluation and improvement, we aim (1) at identifying the optimum degree of complexity required and sufficient in global models to simulate snow-related processes satisfyingly on large scales, (2) at identifying previously unrecognized weaknesses in these models, and (3) at identifying feasible ways to correct these by including relevant processes and setting model parameters judiciously. Besides the site simulations using the reference model set-up, additional simulations at the same scale are planned to identify the role of specific processes or snow properties such as snow albedo and thermal conductivity. It is hoped that the conjunction of global simulations with long site simulations, including sensitivity tests with simplified parameterizations (e.g. fixed albedo), and the systematic comparison with multi-physics models will provide insights into the optimum degree of complexity for the intended applications of the various model types. Specifically, beyond the minimum number of vertical levels required, we aim at getting a better idea about how finely the time evolution of fundamental physical properties of the snowpack (albedo, density, conductivity, liquid water content) and interactions with vege- tation need to be represented, particularly in climate models, in order to correctly simulate the most climate-relevant snow-related variables (snow fraction, thermal insulation of the underlying soil).

The second major objective of ESM-SnowMIP is to better quantify snow-related global climate feedbacks. In LS3MIP, simulations extending the Global LandAtmosphere Coupling Experiment-CMIP (GLACE-CMIP) approach (Seneviratne et al., 2013) are planned to quantify the combined land surface feedbacks involving snow and soil moisture on interannual timescales and in the context of projected future climate change. Complementary coordinated simulations in ESM-SnowMIP, described in the relevant section of this paper, aim at separating the effect of snow from that of soil moisture in order to quantify each of these independently. To this end, diagnoses of snow shortwave radiative forcing as simulated by the participating ESMs are carried out. Snow shortwave radiative forcing is a metric of the radiative effect of snow cover within the climate system (Flanner et al., 2011). ESM-SnowMIP is also complementary to the Polar Amplification Model Intercomparison Project (PAMIP: Smith et al., 2018), which aims at investigating the climate feedbacks related to sea ice changes.

ESM-SnowMIP is part of the World Climate Research Programme (WCRP) Grand Challenge "Melting Ice and Global Consequences" (https://www.wcrp-climate.org/ grand-challenges/grand-challenges-overview, last access: 3 December 2018). As such, it is intended to ensure progress in the understanding of snow-related processes and feedbacks in the global climate and their depiction in global climate models in the context of ongoing global changes, which are characterized by a decrease in the extent and mass of the global cryosphere.

\section{Experimental design and analysis strategy}

As in CMIP6, experiments in ESM-SnowMIP are tiered. Tier 1 simulations are mandatory for all participating groups, provided their model structure is adapted to the specific experiment; exceptions are snow models that are not part of an ESM and which therefore do not participate in the coupled experiments, even those that are labelled as Tier 1 . The number of groups participating in Tier 2 simulations will necessarily be lower than or equal to those participating in Tier 1 experiments; we anticipate that not all proposed Tier 2 experiments will necessarily attract a sufficient number of participating groups for a meaningful multi-model analysis to be possible.

Global snow simulations are subject to uncertainty in the meteorological data used to drive models (whether provided by bias-corrected reanalyses as in LS3MIP offline land model experiments or by coupling with atmospheric models as in CMIP6); global products providing vegetation and soil characteristics for model parameters are often contradictory, 
and global observations of snow properties for evaluation of models (e.g. for snow density and thermal conductivity) are limited. To gain more insight into the behaviour of models in coupled and uncoupled global snow simulations, ESMSnowMIP includes experiments using high-quality driving and evaluation data from well-instrumented reference sites.

Only climate models will be able to perform the global coupled simulations required for CMIP6, and their land surface models will carry out global uncoupled simulations driven with a prescribed meteorological forcing. However, all models - both those that are coupled to an atmospheric model and those that are not (i.e. stand-alone snow models) - can perform the local uncoupled reference site simulations for ESM-SnowMIP at much lower computational expense. Models that have already completed the first round of reference site simulations, listed in Table 1, include land surface schemes (LSS) of CMIP6 models, stand-alone snow physics models, hydrological models, and multi-physics ensemble models.

The experiments proposed in ESM-SnowMIP, with links to relevant LS3MIP reference simulations where appropriate, are listed in Table 2 and described in detail in this section. First, we describe single-point experiments, part of which have already been carried out and are currently being analysed. Then, the spatially distributed simulations are described. These latter simulations will be carried out by a subset of the models participating in ESM-SnowMIP, namely global land surface models (LSM) that are also components of an ESM. Finally, we describe planned experiments with land-atmosphere coupling.

\subsection{Local scale}

\subsubsection{Overview of the sites, models, forcing, and evaluation data}

These single-point experiments are enabled by the considerable efforts of organizations maintaining the sites to compile, quality control, gap fill, and publish their data. Even these reference sites cannot provide all of the input data required by the most sophisticated snow physics models, such as shortwave radiation partitioned into direct and diffuse components or aerosol deposition fluxes. Details on the sites used in a first round of ESM-SnowMIP reference site simulations that have already been completed are given in Table 3, and temperature and snowfall statistics are shown in Fig. 1 (the forcing data provide separate rainfall and snowfall rates). Alpine, Arctic, boreal, and maritime sites have been included in the first round of simulations, and a second round will introduce tundra and glacier sites. The challenges of maintaining unattended hydrometeorological measurements in cold and snowy environments and a requirement for multiple years of data limit the number of possible sites, but the range of sites and the numbers of years simu-

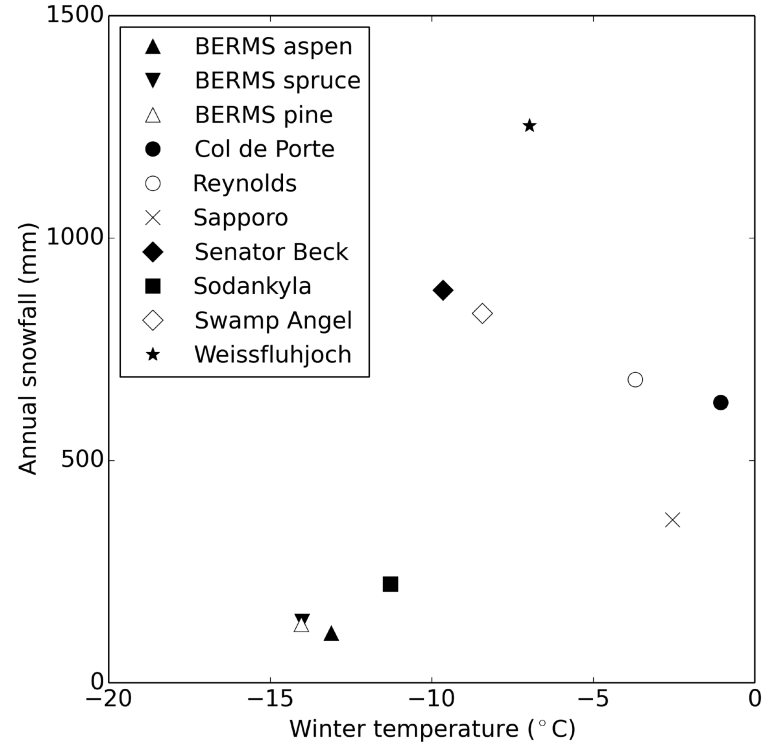

Figure 1. Winter (DJF) temperatures and annual snowfall averaged over the forcing data periods at the ESM-SnowMIP reference sites (see Table 3).

lated in ESM-SnowMIP far exceed those in similar experiments for SnowMIP and PILPS2d.

\subsubsection{Tier 1: reference site simulations (Ref-Site)}

Measurements of snow water equivalent (SWE) and depth, and thus also bulk snow density, are available for all of the reference sites. Several sites also have albedo, surface temperature, and soil temperature measurements. As examples, Figs. 2 and 3 show measurements and simulations at Col de Porte, which has mild and wet winters, and Sodankylä, which is cold and dry. Observations of SWE, snow depth, surface albedo, and soil temperature are within the model spread and close to the model ensemble means. At the warmer site, the simulations of SWE and depth spread out rapidly as snow accumulates, but most of the soil temperature simulations remain within a relatively narrow range. Some models have rather low albedos, leading to early melt, and other models melt the snow too late. Apart from a few outliers, SWE simulations at the colder site remain tightly bunched until the spring, but there is a wide spread in winter soil temperature simulations. Some models maintain soil temperatures under snow close to $0{ }^{\circ} \mathrm{C}$, whereas other models are much too cold. For both sites, there is a strong reduction in model temperature spread as soils cool in autumn before the onset of snow cover and soil freezing.

With several observed variables available for comparison with model outputs and several metrics that can be used for measuring the match between models and observations, there are many ways in which the reference site simulations 
Table 1. Models performing ESM-SnowMIP reference site simulations.

\begin{tabular}{|c|c|c|}
\hline Model & Type & Reference \\
\hline BCC_AVIM & LSS in BCC-ESM & Based on Oleson et al. (2004) \\
\hline CABLE & LSS in ACCESS & Cuntz and Haverd (2018) \\
\hline CRHM & hydrological model & Pomeroy et al. (2012) \\
\hline CLASS & LSS in CanESM & Bartlett et al. (2006) \\
\hline CLM5 & LSS in CESM & Lawrence et al. (2018) \\
\hline CoLM & LSS in BNU-ESM and CAS-ESM & Dai et al. (2003) \\
\hline Crocus & snow physics model & Vionnet et al. (2012) \\
\hline EC-Earth & LSS in EC-Earth & Dutra et al. (2010) \\
\hline ESCIMO & snow surface energy balance model & Marke et al. (2016) \\
\hline ESCROC & multi-physics snow model (35-member ensemble) & Lafaysse et al. (2017) \\
\hline FSM & multi-physics snow model (32-member ensemble) & Essery $(2015)$ \\
\hline HTESSEL & LSS of ECMWF operational forecasting system & Dutra et al. (2012) \\
\hline HTESSELML & LSS of ECMWF forecasting system (research) & Dutra et al. (2012) \\
\hline ISBA-ES & LSS in CNRM-CM & Decharme et al. (2016) \\
\hline ISBA-MEB & LSS in CNRM-CM & Boone and Etchevers (2001) \\
\hline JSBACH & LSS in MPI-ESM & Roeckner et al. (2003) \\
\hline JSBACH3_PF & LSS in MPI-ESM & Ekici et al. (2014) \\
\hline JULES & LSS in UKESM & Best et al. (2011) \\
\hline MATSIRO & LSS in MIROC & Tatebe et al. (2018) \\
\hline MOSES & LSS in HadCM3 & Cox et al. (1999) \\
\hline ORCHIDEE-E & LSS in IPSL-CM & Wang et al. (2013) \\
\hline ORCHIDEE-I & LSS in IPSL-CM & Wang et al. (2013) \\
\hline RUC & LSS in NOAA/NCEP operational forecasting systems & Smirnova et al. (2016) \\
\hline SMAP & snow physics model & Niwano et al. (2014) \\
\hline SNOWPACK & snow physics model & Lehning et al. (1999) \\
\hline SPONSOR & hydrological model & Turkov and Sokratov (2016) \\
\hline SWAP & LSS & Gusev and Nasonova (2003) \\
\hline VEG3D & soil and vegetation model & Braun and Schädler (2005) \\
\hline
\end{tabular}
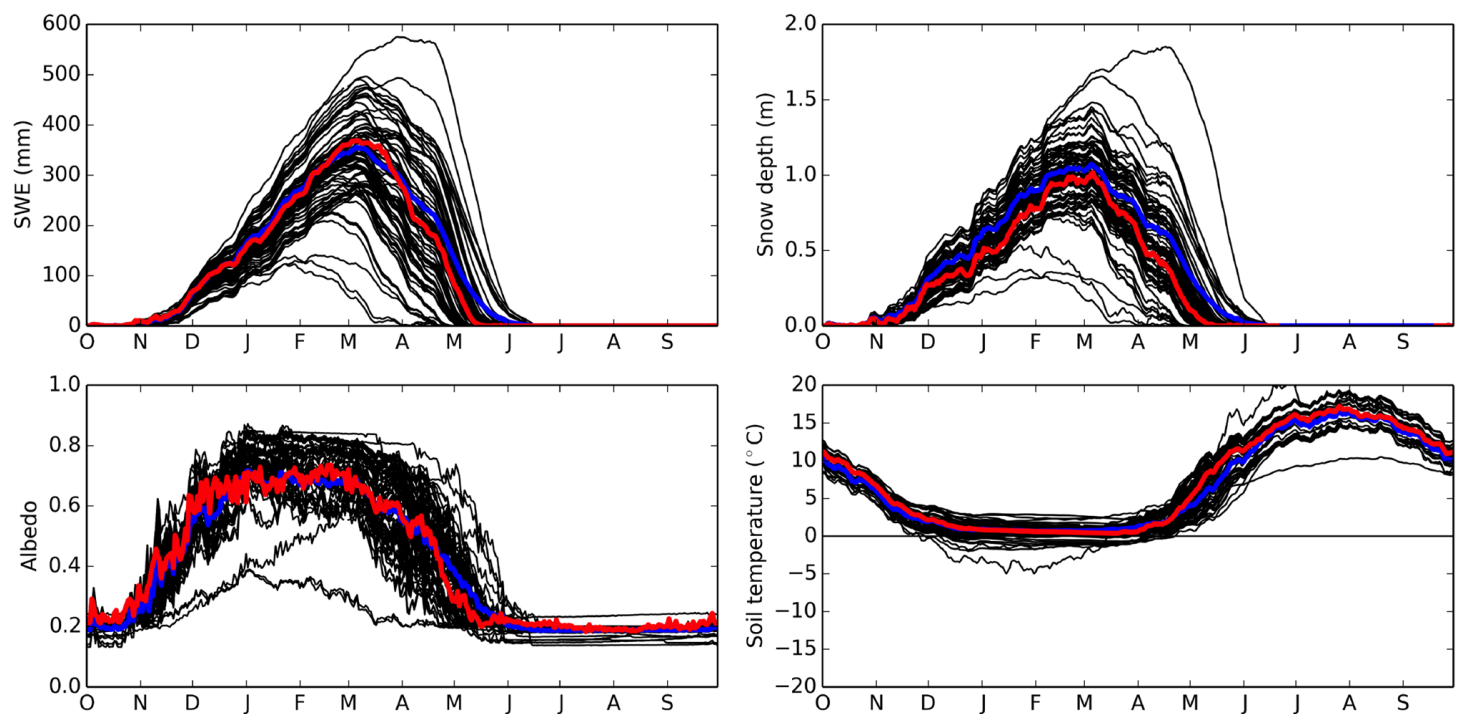

Figure 2. Measurements (red lines), simulations (black lines), and averages of simulations (blue lines) of SWE, snow depth, albedo, and soil temperature at $20 \mathrm{~cm}$ of depth for Col de Porte averaged over October 1994 to September 2014. 


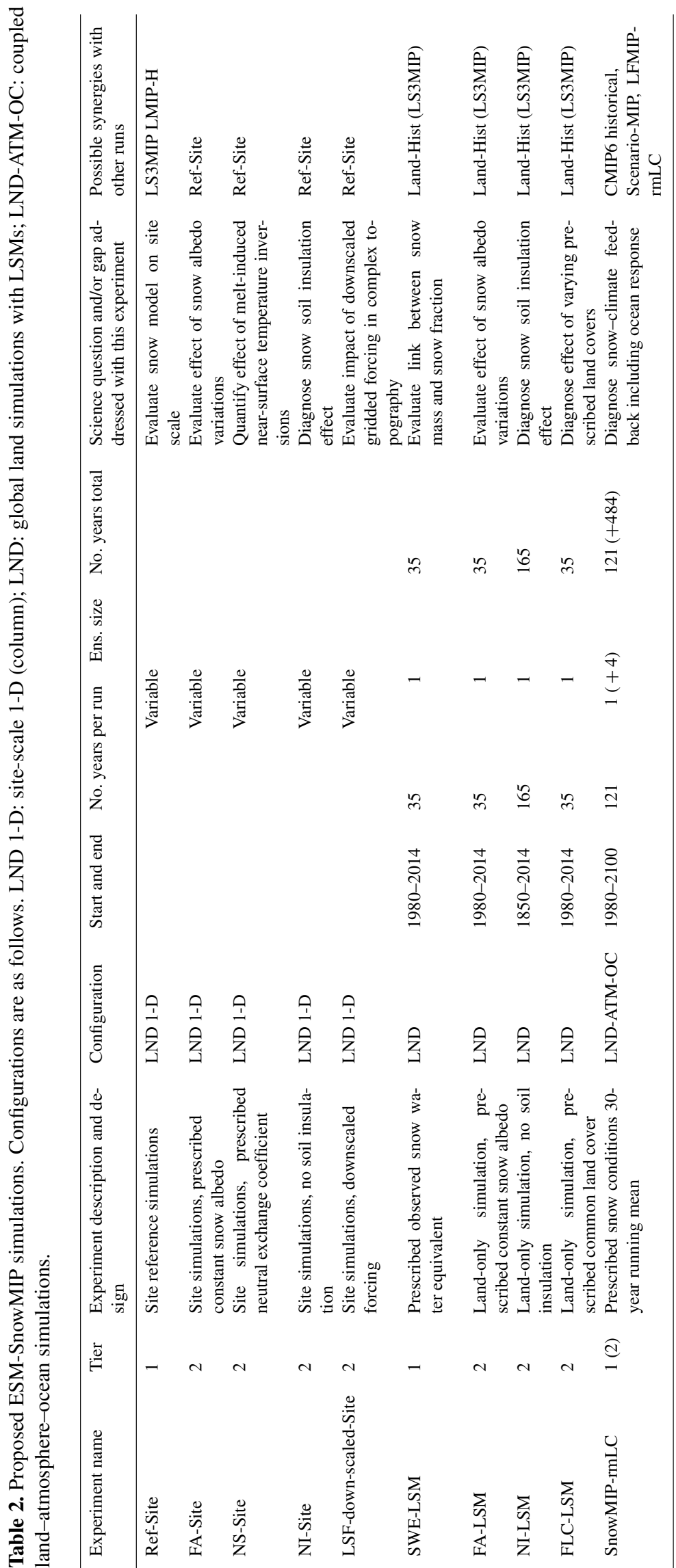


Table 3. ESM-SnowMIP reference sites with abbreviations used in Fig. 4.

\begin{tabular}{llllllll}
\hline Site & Site (short) & Latitude & Longitude & Elevation & Period & Type & Reference \\
\hline BERMS* Old Aspen, Canada & oas & $53.63^{\circ} \mathrm{N}$ & $106.20^{\circ} \mathrm{W}$ & $600 \mathrm{~m}$ & $1997-2010$ & Boreal & Bartlett et al. (2006) \\
BERMS Old Black Spruce, Canada & obs & $53.99^{\circ} \mathrm{N}$ & $105.12^{\circ} \mathrm{W}$ & $629 \mathrm{~m}$ & $1997-2010$ & Boreal & Bartlett et al. (2006) \\
BERMS Old Jack Pine, Canada & ojp & $53.92^{\circ} \mathrm{N}$ & $104.69^{\circ} \mathrm{W}$ & $579 \mathrm{~m}$ & $1997-2010$ & Boreal & Bartlett et al. (2006) \\
Col de Porte, France & cdp & $45.30^{\circ} \mathrm{N}$ & $5.77^{\circ} \mathrm{E}$ & $1325 \mathrm{~m}$ & $1994-2014$ & Alpine & Lejeune et al. (2018) \\
Reynolds Mountain East, USA & rme & $43.06^{\circ} \mathrm{N}$ & $116.75^{\circ} \mathrm{W}$ & $2060 \mathrm{~m}$ & $1988-2008$ & Alpine & Reba et al. (2011) \\
Sapporo, Japan & sap & $43.08^{\circ} \mathrm{N}$ & $141.34^{\circ} \mathrm{E}$ & $15 \mathrm{~m}$ & $2005-2015$ & Maritime & Niwano et al. (2012) \\
Senator Beck, USA & snb & $37.91^{\circ} \mathrm{N}$ & $107.73^{\circ} \mathrm{W}$ & $3714 \mathrm{~m}$ & $2005-2015$ & Alpine & Landry et al. (2014) \\
Sodankylä, Finland & sod & $67.37^{\circ} \mathrm{N}$ & $26.63^{\circ} \mathrm{E}$ & $179 \mathrm{~m}$ & $2007-2014$ & Arctic & Essery et al. (2016) \\
Swamp Angel, USA & swa & $37.91^{\circ} \mathrm{N}$ & $107.71^{\circ} \mathrm{W}$ & $3371 \mathrm{~m}$ & $2005-2015$ & Alpine & Landry et al. (2014) \\
Weissfluhjoch, Switzerland & wfj & $46.83^{\circ} \mathrm{N}$ & $9.81^{\circ} \mathrm{E}$ & $2540 \mathrm{~m}$ & $1996-2016$ & Alpine & WSL (2017) \\
\hline
\end{tabular}

* BERMS: Boreal Ecosystem Research and Monitoring Sites.
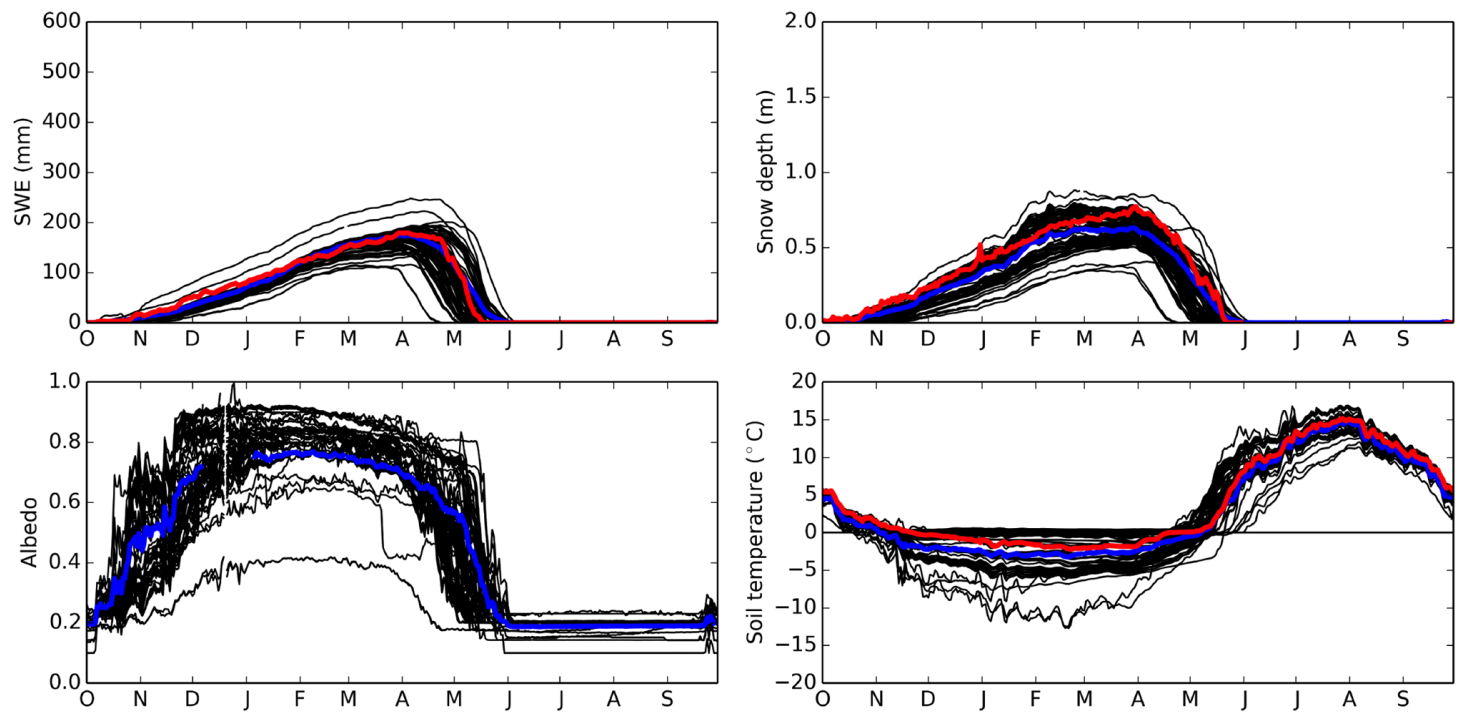

Figure 3. As Fig. 2, but for October 2007 to September 2014 at Sodankylä (albedo measurements are not available for the snow surface).

could be evaluated and ranked. Figure 4 shows one example, in which root mean squared errors in simulated SWE have been calculated for each model at each site and normalized by the standard deviation of measured SWE at the given site for comparison between sites. A value greater than 1 for this metric shows that a model fits variations in the observations no better than the average of all observations. Ranking models according to their average error for all sites shows that a couple of models perform well and a couple perform poorly at all sites, but most models perform well at some sites and poorly at others. Many models have larger errors for the forested sites than the open sites and larger errors for warmer sites than colder sites. The ensemble mean of the models has lower errors than the majority of the individual models at most of the sites. The only individual models to have normalized errors less than 1 for all sites are the Crocus snow physics model and the HTESSEL and SWAP land surface schemes, which have very different complexity. This illustrates that model complexity per se does not explain the spread in performance observed here. There will be a thorough evaluation of model performance in a forthcoming paper.

\subsubsection{Tier 2 site simulations}

Snow mass balance is influenced by radiated, advected, and conducted heat fluxes in the energy balance. Soil temperature is influenced by snow depth, thermal conductivity, amount of meltwater refreezing, and refreezing depth (van Kampenhout et al., 2017). To investigate how these influences differ between models, additional experiments are proposed with prescribed snow albedo, with prescribed aerodynamic parameters, and with the thermal insulation of snow removed. These experiments have not started yet, but pilot studies have been conducted using version 2 of the Factorial Snow Model (FSM, Essery, 2015); this is a multi-physics model designed 

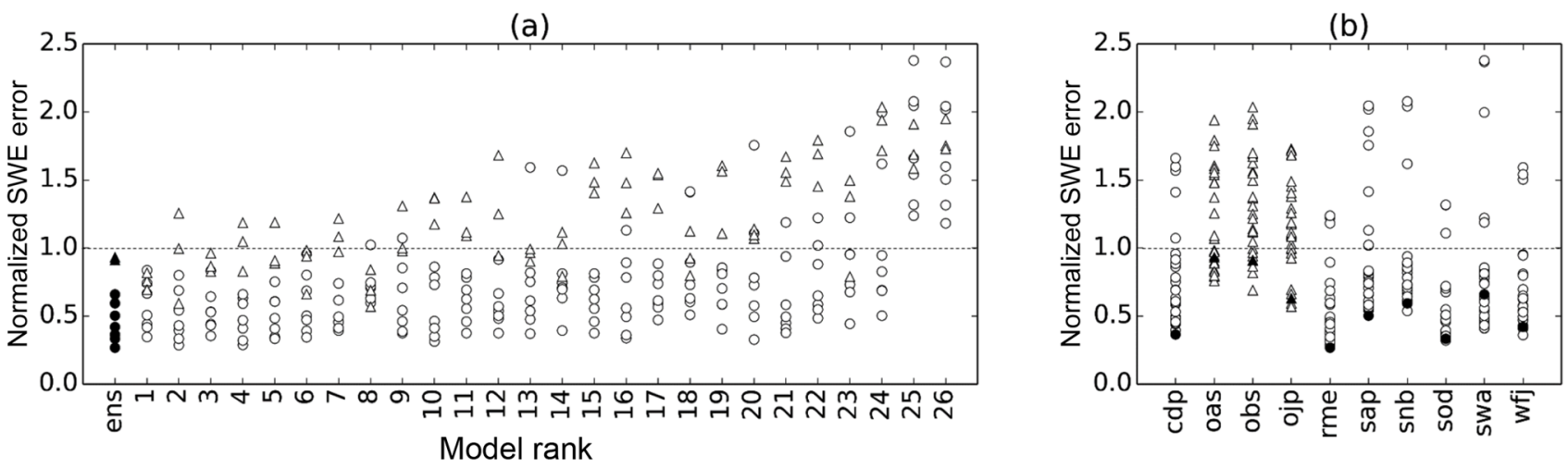

Figure 4. Normalized root mean square SWE errors for the 26 non-ensemble models in Table 1 returning a single simulation for each site (white symbols) and the 26-model ensemble mean (black symbols), with simulations identified by circles at open sites and triangles at forested sites. (a) Models ranked according to their average error for all sites. (b) Errors for all models at each site (for abbreviations see Fig. 4).

to run ensembles of simulations producing a range of model behaviours by using alternative parameterizations for snow albedo, thermal conductivity, compaction, liquid water storage, and coupling with the atmosphere. The pilot studies using FSM allow for the validation of the intended experiment set-up, provide a benchmark for model spread, and facilitate the interpretation of the results.

Fixed snow albedo (FA-Site). Seasonal and subseasonal variations of snow albedo are substantial and strongly influence the energy balance of the snowpack. This is particularly important during the melting season when complex processes within the snowpack lead to strong and rapid variations of albedo. Positive albedo feedbacks strongly influence melt timing. Snowmelt timing is a critical climatic metric that is often incorrectly simulated by climate and dedicated snow models, but it is difficult to untangle the effects of the simulation of snow albedo from other processes because of the strong feedbacks involved (Mudryk et al., 2017; Qu and Hall, 2014). An experiment in which snow albedo is fixed to 0.7, which is a typical snow pre-melt albedo (Harding and Pomeroy, 1996; Melloh et al., 2002; Wang et al., 2016), will enable evaluation of the effect of seasonal snow albedo variations and biases.

Differences between an ensemble of fixed snow albedo simulations with FSM and reference simulations for Col de Porte are shown in Fig. 5. Ensemble members differ widely in their responses to the removal of snow albedo feedbacks. Fixing the snow albedo prevents it from decreasing as the snow melts and delays the snowmelt. Extending the duration of snow cover as a result delays warming of the soil in spring, leading to large temperature differences when snow remains in a fixed albedo simulation but has disappeared in the corresponding reference simulation.

No suppression of fluxes in stable surface layers over snow (NS-Site). Models generally calculate turbulent heat fluxes in the atmospheric boundary layer using exchange coefficients that only depend on surface roughness and wind speed in neutral conditions but are reduced in stable conditions by a factor depending on a Richardson number or an Obukhov length. The strength of this decoupling between the atmosphere and the surface is a major source of uncertainty in climate and snow models (Schlögl et al., 2017) and will influence how strongly snowmelt responds to warming of the atmosphere. The coupling strength in a model will be quantified by an additional experiment in which exchange coefficients are kept fixed at neutral values.

FSM only has a single option for stability adjustment of the surface exchange coefficient, but ensemble members still respond differently to switching this option off, as seen in Fig. 6. Snow-free soil temperatures would also be influenced, so the fix is only applied when snow is on the ground. With heat transfers predominantly being downwards from the atmosphere to snow, fixing the exchange coefficient increases the heat transfer and warms the snow surface, often leading to decreases in snow albedo and earlier melt. The soil warms rapidly in spring when the snow melts, but winter soil temperatures can also be increased relative to the reference simulation despite the decrease in insulating snow depth because of the increased heat flux from the atmosphere.

No thermal insulation by snow (NI-Site). The low thermal conductivity of snow has a major climatic control on the temperature of underlying soils and heat fluxes to the atmosphere that is spatially and temporally variable and often not well represented in climate models (Koven et al., 2013). This insulating effect might be quantified by an experiment in which snow takes a very high (effectively infinite) thermal conductivity, while its other properties (albedo, latent heat of melting, etc.) are kept unchanged. In practice, the numerical scheme of a model might become unstable for high thermal conductivities and another solution might be envisaged, such 

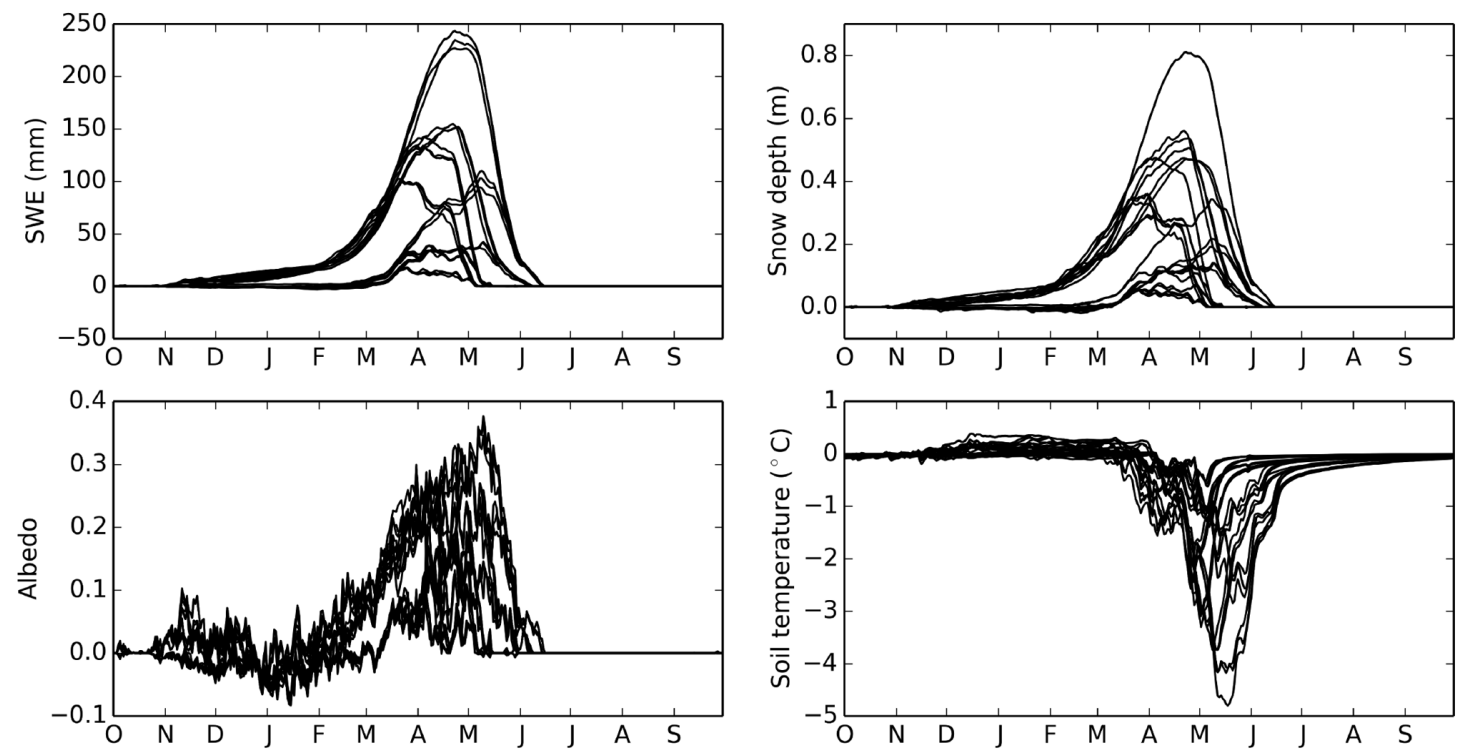

Figure 5. Differences between the 32 FSM ensemble members in fixed albedo and reference simulations for Col de Porte averaged over October 1994 to September 2014.
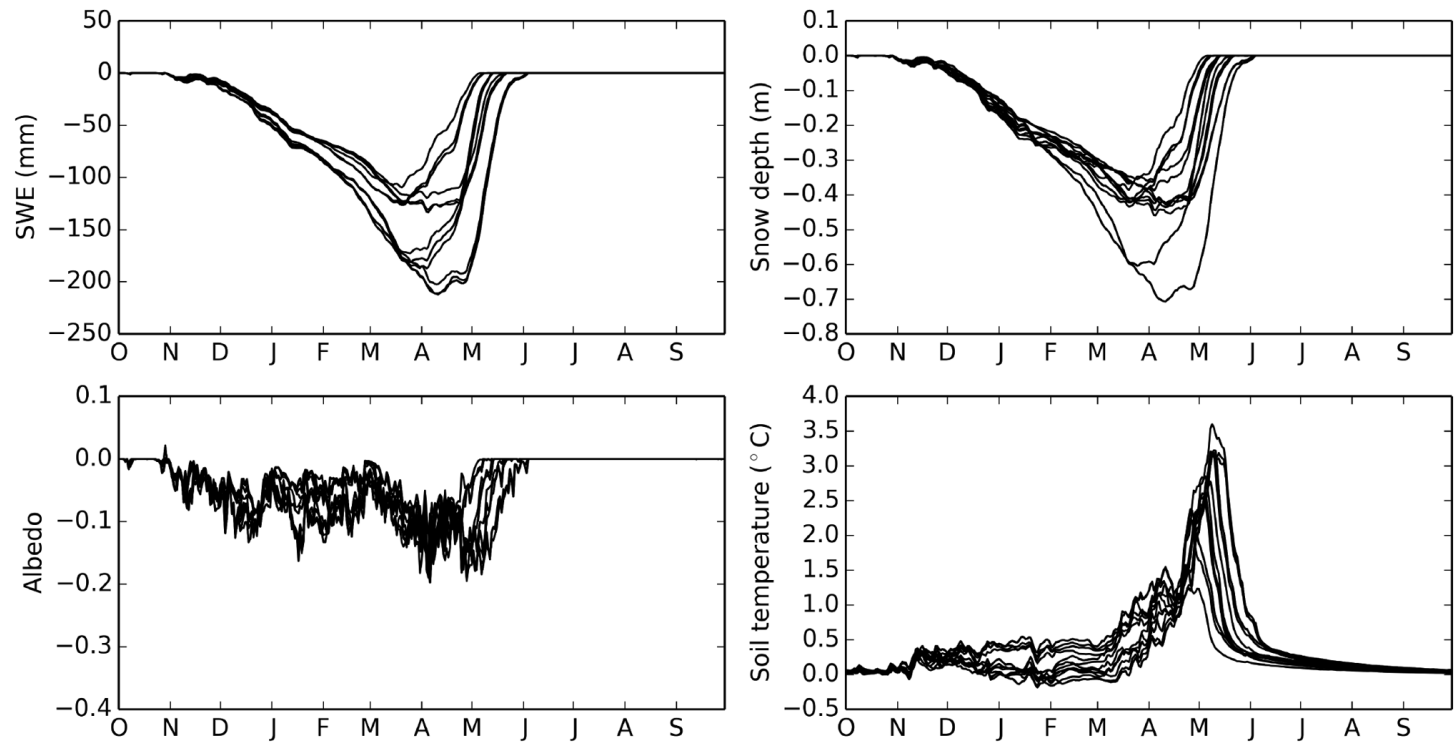

Figure 6. As Fig. 5, but for differences between 16 FSM ensemble members with fixed surface exchange coefficients and 16 with variable coefficients.

as resetting the temperature or the net heat flux at the soilsnow interface to that calculated at the snow surface.

In a pilot study, FSM simulations were found to be numerically stable with a fixed $50 \mathrm{~W} \mathrm{~m}^{-1} \mathrm{~K}^{-1}$ thermal conductivity for snow, which is much higher than a typical range of 0.05 to $0.5 \mathrm{~W} \mathrm{~m}^{-1} \mathrm{~K}^{-1}$ (Sturm et al., 1997). This value of thermal conductivity led to vanishing temperature gradients across the snowpack and was therefore deemed high enough without compromising numerical stability. Results are shown in
Fig. 7. Without the insulating effect of snow, the soil freezes even in the relatively mild winters at Col de Porte. Building up a cold reservoir in the soil over winter has a secondary effect of delaying snowmelt in spring. Even without the insulating effect, the high albedo of snow and energy required for snowmelt reduce the amount of energy to warm the soil, leading to a second trough in soil temperature differences between high thermal conductivity and reference simulations. 

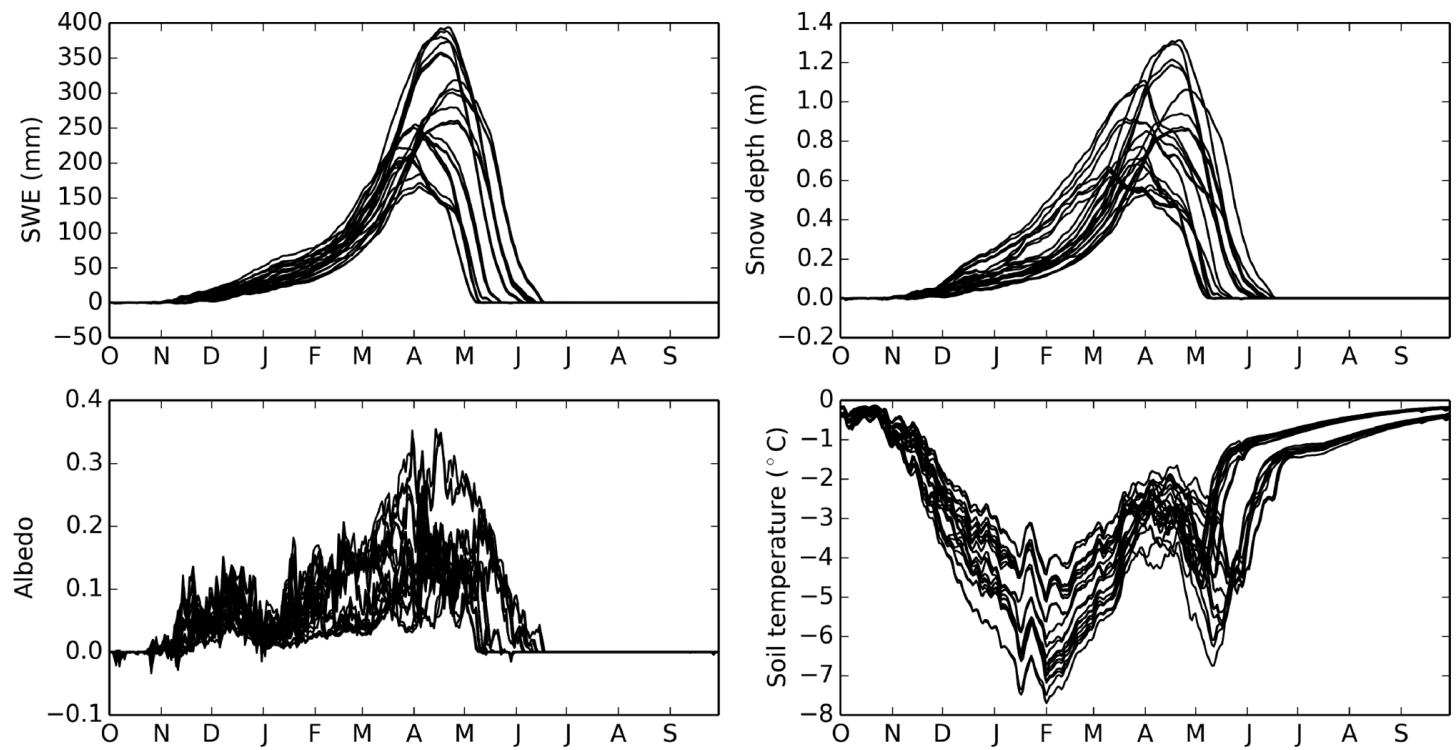

Figure 7. As Fig. 5, but for differences between the 32 FSM ensemble members in simulations without thermal insulation by snow and reference simulations.

Downscaled large-scale forcing (LSF-downscaled-Site). Most of the mid-latitude ESM-SnowMIP reference sites were established for snow research in mountainous regions and are at higher elevations than much of the surrounding terrain. Meteorological variables in large-scale forcing datasets, such as the GSWP3 (Global Soil Water Project Phase 3) meteorological forcing data provided at $0.5^{\circ}$ spatial resolution for LS3MIP (Kim et al., 2017), would therefore be expected to be biased relative to in situ measurements at the sites even if they were perfect on the grid scale. Col de Porte, for example, is located at an elevation of $1325 \mathrm{~m}$ in the French Chartreuse Mountains but lies within a $0.5^{\circ}$ grid cell with an average elevation of $870 \mathrm{~m}$. Figure $8 \mathrm{a}$ shows that an FSM simulation for winter 2009-2010 at Col de Porte with GSWP3 driving data gives almost no snow accumulation; this is because temperature on the grid scale, because of the lower mean altitude, is higher than at Col de Porte, while total precipitation is lower and snowfall is much lower. Site and grid elevations for Sodankylä, in contrast, only differ by $40 \mathrm{~m}$ because this site is situated in a flat area. The large-scale simulation shown in Fig. $8 \mathrm{~b}$ is not so strongly influenced by driving data biases.

Downscaling is commonly required when using regional climate predictions in hydrological impact studies. An ESMSnowMIP experiment with altitude-adjusted large-scale driving data will be helpful in using reference site observations and simulations to evaluate the performance of models in large-scale simulations. Simply removing average altituderelated errors in the GSWP3 driving data, with no attempt to adjust variations on interannual and shorter timescales, greatly improves the SWE simulation for Col de Porte, re- placing a massive underestimate with a slight overestimate (Fig. 8a). For Sodankylä, removing the smaller long-term driving data biases has very little effect on the SWE simulation (Fig. 8b).

We expect the Tier 2 site simulations with the individual models to essentially align with the FSM results presented here. However, we also expect a varying degree of sensitivity of the various models to the different model parameter and set-up changes, which will allow for the identification of unique priorities for the development of each of the participating models.

\subsection{Global scale}

\subsubsection{Large-scale observational data}

Observation-based estimates of SWE and snow cover fraction $(\mathrm{SCF})$ are required for the evaluation of historical mean and model spread from ESM-, AMIP-, and LMIP- type simulations, as well as prescribed historical SWE and SCF as required for specific experiments. For this purpose, we will employ a blended dataset of snow products from ERAInterim/Land (Balsamo et al., 2015), MERRA (Rienecker et al., 2011), ERA-Crocus (Brun et al., 2013), ESA-GlobSnow (Takala et al., 2011), and GLDAS-2 (Rodell et al., 2004). These SWE datasets were assessed previously for temporal and spatial consistency by Mudryk et al. (2015), who proposed a climatology derived from a combination of these five datasets.

The rationale for using a blended suite of snow products is threefold. First, it provides a measure of historical observational uncertainty given by the range of estimates from indi- 

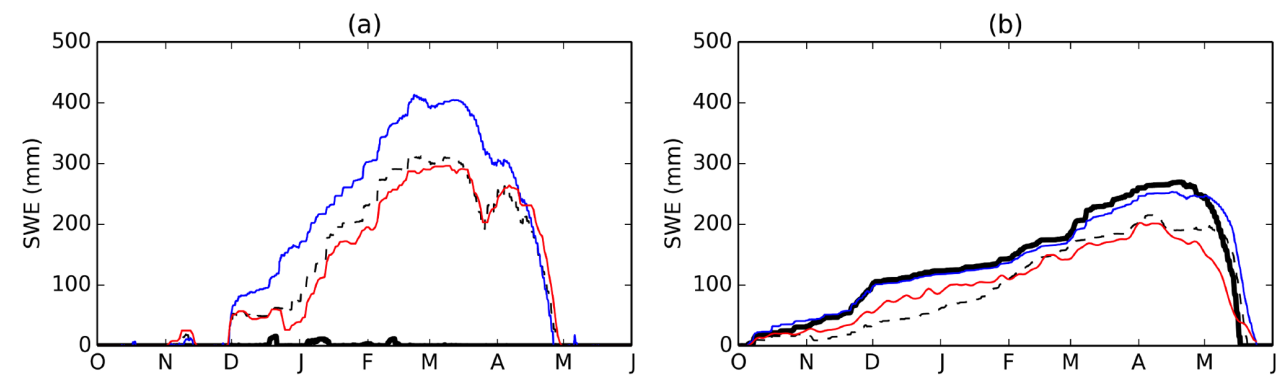

Figure 8. Simulations with a single FSM ensemble member and in situ driving data (dashed black lines), large-scale GSWP3 driving data (solid black lines), or bias-corrected GSWP3 driving data (blue lines) compared with in situ SWE measurements (red lines) for 2009-2010 at (a) Col de Porte and (b) Sodankylä.

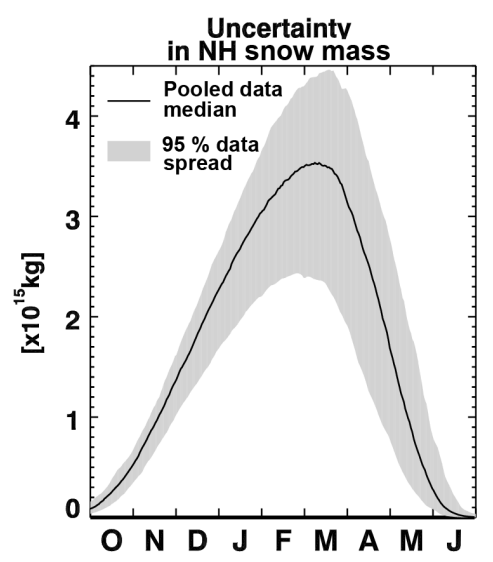

Figure 9. Daily median and spread (5th-95th percentile) among the five snow products listed above for the 1981-2010 period.

vidual analyses. This is demonstrated in Fig. 9, which shows the daily median and spread (5th-95th percentile) among the five snow products listed above for the 1981-2010 seasonal SWE climatology. For a given day, statistics are calculated from the pooled distribution of data across the 30-year period and across all five datasets. As analysed in Mudryk et al. (2015), the range across the snow products likely results from differences in the snow schemes within the land surface models, differences in precipitation and temperature in the forcing meteorology (from various reanalyses), and the impact of satellite and weather station measurements (used in GlobSnow and ERA-Brown). Still, the illustrated spread is a useful proxy for observation-based uncertainty (which cannot be determined when a single product is applied for evaluation) and may be used to evaluate the corresponding level of agreement from LS3MIP and ESM-SnowMIP simulations over a similar historical period.

A second reason to use a suite of analyses for MIP evaluation is that the bias and error of individual datasets vary with geographical location and datasets that perform well in some regions may perform more poorly in others. The lack of a clear "best" dataset provides minimal reason to favour one analysis over another. In fact, it has been explicitly demonstrated that combinations of products have both lower bias and RMSE than individual products when evaluated over domains with in situ data (Schwaizer et al., 2016). For this reason, a blended combination of snow products will be used for time-varying prescribed SWE simulations (see Sect. 3.2.2) and could also be used for evaluation of SWE output from simulations which are observationally constrained by nonsnow-related variables.

Finally, the use of SWE analyses also allows for the definition of a mutually consistent set of snow cover extent (SCE) data by choosing a seasonal and climatological SWE threshold above which a grid cell is considered snow-covered. The spread of total NH SCE estimated from a range of thresholds between 0 and $10 \mathrm{~mm}$ is large (Fig. 10a; light shading) with much of the uncertainty related to very low SWE thresholds $(<2 \mathrm{~mm})$, for which reanalysis-based SWE persists on the land surface for physically unrealistic amounts of time. Optimization based on satellite-based observations of climatological SCE has identified $5 \mathrm{~mm}$ as a reasonable choice of threshold (Fig. 10a; dark shading) for deriving SCE from SWE (Robinson et al., 2014).

\subsubsection{Global land-only simulations}

The global land-only simulations planned in ESM-SnowMIP build on the reference historical land simulation (LandHist) currently carried out in the framework of the LS3MIP project. The aim of this 1850-2014 simulation, using GSWP3 meteorological forcing, is to provide a land-only simulation carried out with the land surface modules used in the CMIP6 ESMs at the same resolution as used in the coupled model, allowing for the separate evaluation of the land surface components of these models and potentially attributing sources of coupled model biases to the individual coupled model components. The global land simulations planned in ESM-SnowMIP share the model set-up with this Land-Hist simulation to optimize complementarity. 
(a) Observational SCE estimates

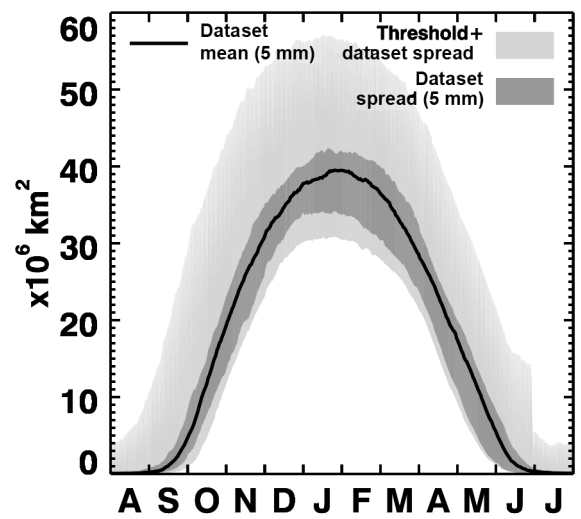

(b) January SCE spread

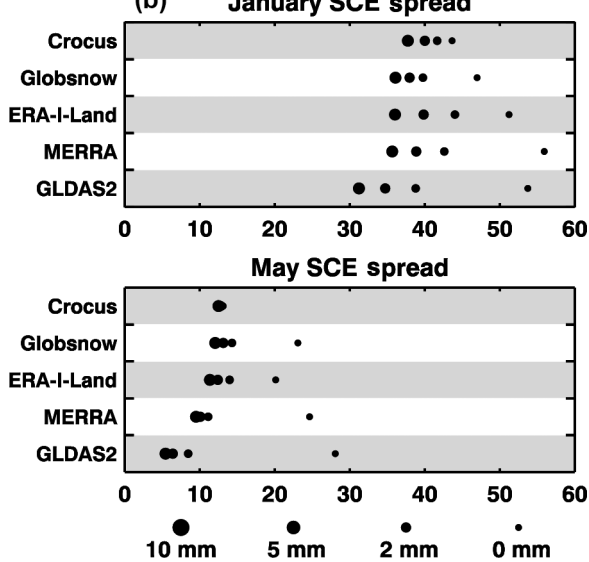

Figure 10. (a) Daily median and spread (5th-95th percentile) among the five snow products for SCE calculated using a $5 \mathrm{~mm}$ SWE threshold (solid curve and dark shading) and spread calculated using a range of thresholds between 0 and $10 \mathrm{~mm}$ (light shading). (b) January and May SCE for four choices of thresholds.

Tier 1: prescribed observed snow water equivalent (SWE$L S M)$. The relationship between grid-scale snow water equivalent (SWE), fractional snow cover, and hence surface albedo is complicated and very diverse solutions are presently implemented in coupled climate models. Here we propose a prescribed SWE experiment to identify LSM biases that are linked to the parameterization of surface albedo as a function of the snow cover fraction, which in turn is very often a diagnostic function of the SWE which is prescribed in this experiment. The aim is to evaluate the simulated grid-scale albedo in these simulations against satellite-based observations of surface albedo.

Simulated grid-scale surface albedo in the presence of snow can depend explicitly on subgrid-scale topography, parameterized patchiness, vegetation cover, snow albedo, and other factors. The vegetation cover dependence includes explicitly simulated masking of vegetation by snow or vice versa. In particular, the albedo effect of transient snow load on trees after snowfall with subsequent unloading due to wind and melting, which is sometimes represented in current-generation ESM snow modules, should not be offset by too simple a prescription of observed SWE. It should therefore be left up to the modelling groups to decide exactly how SWE is prescribed in their models. However, the model SWE should satisfy the condition that the weekly average SWE in the model is close to the observed value (by less than $10 \%$ ). This can, for example, be obtained by a Newtonian relaxation of SWE to the weekly average with a time constant of a few days. Other state variables of the snow module (e.g. snow internal temperature, water content, snow grain size, etc.) will have to be adapted accordingly; again, given the diversity of snow modules, it is impossible to define here exactly how this needs to be done in general. Note that these considerations also apply for the land-only simulations of LS3MIP in which soil wetness and SWE are to be pre- scribed. In cases of snow modules for which an unequivocal relationship ties surface albedo to SWE, it might be sufficient to run only the albedo scheme with prescribed SWE as input.

While a number of snow products are available to serve as prescribed SWE, we recommend the Mudryk et al. (2015) combined climatology (see Sect. 3.2.1) for ESM-SnowMIP simulations. Because biases in individual products are compensated for through averaging, this dataset represents an improved reference for model evaluation compared to any single-component dataset (Sospedra-Alfonso et al., 2016), just like a climate model ensemble mean is often preferred over a single member.

The simulated surface albedo will be compared to surface albedo as derived from satellite observations (MODIS, Schaaf et al., 2002; APP-x, Wang and Key, 2005; GlobAlbedo, Lewis et al., 2012). In particular, the change in the quality of the simulated surface albedo compared to the "free" LS3MIP Land-Hist simulation and the historical CMIP6 simulation will be evaluated in order to infer the part of surface albedo errors linked to a biased snow mass balance.

Tier 2: fixed snow albedo (FA-LSM). This is a spatially distributed version of the FA-Site simulation described above. It consists of prescribing snow albedo to a fixed value of 0.7. The aim of the experiment is, similar to that of the FASite simulation, to enable evaluation of the effect of seasonal snow albedo variations and biases in LSMs, although the model response will depend very much on how snow masking by vegetation is parameterized.

Simulated snow water equivalent (SWE), fractional snow cover, and vegetation masking will still influence the gridpoint average surface albedo. The simulation period is 1980 2014, as in the Land-Hist and SWE-LSM simulations. If possible, the fixed snow albedo value should also be used over ice sheets. Correct prescription of snow albedo can be ver- 
ified by checking grid-scale average surface albedo in areas with deep snow cover and low vegetation. In addition, the effect of vegetation masking on surface albedo in snowcovered areas will be isolated, since the snow-vegetation parameterizations will vary between models, but snow albedo will remain fixed.

This simulation is tightly linked to the LS3MIP Land-Hist offline reference simulation. In synergy with the site simulation with prescribed snow albedo (FA-Site), comparison with the same period in the reference simulation allows for the evaluation of the effect of snow albedo in terms of timing of snowmelt, winter season surface temperature, and energy flux partitioning as a source of model biases. In addition, the effect of vegetation masking on surface albedo in snowcovered areas will be isolated, since the snow-vegetation parameterizations will vary between models, but snow albedo will remain fixed. Again, as in FA-Site, a basic metric to evaluate the effect of prescribed snow albedo will be the duration of snow cover (in particular melt onset) in this experiment compared to the reference simulation and observation. Required observations therefore concern snow cover seasonality, in particular snowmelt dates (to be obtained from the ensemble of large-scale SCE data), and general climate variables such as surface air temperature.

Tier 2: no thermal insulation by snow (NI-LSM). We propose a global LSM simulation with "infinite" snow conductivity (that is, no effective thermal insulation by snow) as a global extension of the site-scale experiment NI-Site. Again, this simulation will otherwise have an identical set-up as the relevant reference simulation Land-Hist. However, the models might need to be spun up for a substantial number of years in this set-up in order to achieve thermal equilibrium at the lowest soil levels.

In this global setting, simulated potential permafrost extent (that is, the permafrost extent in equilibrium with the prescribed climate and model set-up, also often termed "nearsurface permafrost"; e.g. Lawrence et al., 2008) will be diagnosed from the thermal state of the lowermost soil layer in the simulations. It will be compared to the corresponding output of the Land-Hist reference simulation and GTNP observations (Biskaborn et al., 2015). Required reference data are soil temperature measurements and observations and analyses of surface energy fluxes at all seasons in areas with seasonal snow cover. Again, in the multi-model context, we expect a relationship between the sensitivity of the simulated potential permafrost extent to thermal insulation by soil and diagnosed errors of the simulated near-surface permafrost extent, which we hope will be useful to identify ways for model improvement.

Tier 2: fixed land cover (FLC-LSM). Previous studies show that inaccurate representation of vegetation distribution and parameters in LSMs may result in large biases in simulated surface albedo for snow-covered forests (Essery, 2013; Wang et al., 2016). Most current LSMs represent vegetation from a set of plant functional types (PFTs), which are usually de- rived from global land cover datasets (Bonan et al., 2002; Poulter et al., 2015). There are large differences among PFTs used in LSMs, which may result from the differences in the land cover datasets, the cross-walking tables used to map land cover datasets into PFTs represented in LSMs, or uncertainties in dynamic PFT simulations (Hartley et al., 2017; Poulter et al., 2011). In order to separate biases due to differences in vegetation distribution from those due to physical processes in LSMs, we propose an experiment in which models derive their PFTs from the same land cover dataset and using the same cross-walking table.

Several global land cover datasets are available with spatial resolutions ranging from $300 \mathrm{~m}$ to $1 \mathrm{~km}$ (Bontemps et al., 2012). The newly released European Space Agency (ESA) Climate Change Initiative (CCI) land cover datasets are developed specifically to address the needs of the climate modelling community (Poulter et al., 2015). The CCI maps include 22 level-1 classes and 15 level-2 subclasses based on the United Nations Land Cover Classification System, which was identified as a suitable thematic legend and compatible with the PFT concept of most LSMs (Bontemps et al., 2012). While most previous land cover datasets are for a single year, the CCI datasets are available from 1992-2015 at $300 \mathrm{~m}$ resolution (ESA, 2017). The finer spatial resolution of $300 \mathrm{~m}$ (versus $1 \mathrm{~km}$ ) makes it inherently superior for land cover mapping in heterogeneous landscapes for which different datasets tend to disagree (Fritz et al., 2011; Herold et al., 2008). In addition, a cross-walking table to convert the categorical land cover classes to the fractional area of PFTs was provided with the CCI datasets (Poulter et al., 2015). We thus suggest the use of the CCI land cover dataset for the year 2000 as the common land cover dataset from which to derive PFTs. Different models usually have their own unique set of PFTs. For cases in which both the phenology type and the associated climate zone are considered, the Köppen-Geiger climate classification can be used as in Poulter et al. (2015).

The simulation period of 1980-2014 matches the LS3MIP Land-Hist offline reference simulations. A comparison of the surface albedo with the reference simulation will isolate the impact of PFT distribution on surface albedo and associated feedbacks in snow-covered areas. Since the PFTs are from the same land cover data in the participating models, the differences in surface albedo among the models will reveal differences in snow-vegetation interactions and other vegetation-related parameterizations (e.g. leaf area index) used in the models.

\subsubsection{Global simulation with land-atmosphere coupling: SnowMIP-rmLC}

ESM-SnowMIP proposes one coupled Tier 1 experiment, which serves the purpose of quantifying snow-related feedbacks in the global climate system on interannual timescales. It is designed to separate the effects of snow from the effects of snow and soil humidity, the combined effect being ad- 
dressed by the LS3MIP Tier 1 coupled experiment LFMIPrmLC. This LS3MIP experiment uses 30-year running mean land conditions (snow and soil humidity), as simulated in a reference transient climate change experiment, and prescribes these in a second simulation. In these runs, snow and soil moisture feedbacks on decadal and shorter timescales are muted. Comparing the LFMIP-rmLC simulation to the appropriate projection used for prescribing the land surface conditions allows for the identification of these feedbacks. In the context of a transient run, additional diagnoses of geographic shifts of land-atmosphere coupling hotspots (Seneviratne et al., 2006) and changes in potential predictability related to land surface (Dirmeyer et al., 2013) can be carried out. The SnowMIP-rmLC will isolate the effects of snowatmosphere coupling by prescribing only the soil humidity state from the reference simulation, not the entire surface state as in LFMIP-rmLC.

For the SnowMIP-rmLC experiment, the LFMIP-rmLC experiment set-up is modified such that only the climatological soil humidity is prescribed. Contrary to the LFMIP-rmLC experiment, snow is allowed to evolve freely. The rationale behind this choice is that in this way, our simulation setup is more similar to previous GLACE-CMIP experiments (Seneviratne et al., 2013), while the effect of snow can be deduced from the difference between these two simulations. Because of internal variability in the climate system, a fivemember ensemble simulation would be ideal, but this is expensive. Similar to the LFMIP-rmLC set-up, we propose the first ensemble member as Tier 1 and suggest four other ensemble members as Tier 2 (see Table 2). The simulation period is the same as in LFMIP-rmLC, i.e. 1980-2100. Correct prescription of snow can be verified easily by comparing the simulated SWE for an individual year with the simulated climatological (1980-2014) SWE of the free projection. It should be very close.

The SnowMIP-rmLC experiments will allow for the evaluation of the effect of snow feedbacks on interannual to decadal timescales as well as on the centennial climate change signal (since even by the end of the 21 st century, the 1980-2014 average snow conditions will be used).

The simulation will be analysed in parallel to the LFMIPrmLC simulations, following very closely the methodologies of Seneviratne et al. (2013). Required observations are snow cover seasonality, in particular snowmelt dates, and general climate variables such as surface air temperature, and circulation patterns.

\subsubsection{Snow shortwave radiative effect diagnosis}

Another useful measure of the impact of snow on climate is the snow shortwave radiative effect (SSRE) (e.g. Flanner et al., 2011; Perket et al., 2014; Singh et al., 2015). For the purposes outlined here, SSRE is the instantaneous change in surface absorbed solar energy flux caused by the presence of terrestrial snow. The diagnosis of SSRE provides a precise, overarching measure of the snow-induced perturbation to solar absorption in each model, integrating over the variable influences of vegetation masking, snow grain size, snow cover fraction, soot content, and other factors. SSRE is also a useful measure for climate feedback analysis and has a direct analogue in the widely used "cloud radiative effect". To enable us to calculate and analyse inter-model differences of SSRE and their causes, participating modelling groups are requested to provide specific gridded output (see below) from their LS3MIP Land-Hist and Land-Future simulations, as well as from the ESM-SnowMIP FA-LSM and SWE-LSM simulations. Ideally, these output fields should also be provided for one or more of the coupled atmosphereocean simulations, preferably from the historical reference run.

SSRE can be calculated in a land surface model through the following procedures.

1. Conducting an additional surface albedo calculation at each model time step with zero snow. This implies setting to zero the mass of snow on ground, mass of snow in vegetation canopy, and snow cover fraction, but only for the purpose of this diagnostic albedo calculation. It should have no effect on the prognostic snow simulation.

2. Calculating net and reflected surface solar energy fluxes at each model time step using the diagnostic albedo from (1) and using the same surface downwelling (incident) flux that would otherwise be used to calculate solar heating.

3. Archiving the diagnostic calculations from (1) and (2) at the same frequency as other model output (e.g. daily or monthly).

The following gridded fields should be provided from the model: (1) net surface shortwave irradiance calculated without snow (rss_ nosno); and (2) mean shortwave surface albedo calculated without snow (albs_nosno).

Net surface solar energy flux in the absence of snow can then be differenced from that calculated with snow (output by default) to provide the SSRE.

Although the no-snow albedo fields are not strictly needed for the calculation of SSRE, they will complement standard albedo output from the model to facilitate convenient evaluation and the derivation of hypothetical SSRE from different (e.g. clear-sky) surface downwelling irradiance fields. Depending on the spectral resolution of solar energy in each model, it would also be useful to provide the visible and near-infrared partitions of the following: (1) net surface visible $(0.2-0.7 \mu \mathrm{m})$ irradiance calculated without snow; (2) net surface near-IR $(0.7-5.0 \mu \mathrm{m})$ irradiance calculated without snow; (3) mean visible surface albedo calculated without snow; and (4) mean near-IR surface albedo calculated without snow. 


\subsection{Timeline, data request, and data availability}

The first set of reference site simulations (Ref-Site) have already been carried out and are currently being analysed. The additional site simulations will be carried out in the near future. In 2018 and 2019, the global climate modelling community will be heavily involved in CMIP6. To decrease peak workload on the modelling groups while at the same time optimizing synergies with the CMIP6 activities and in particular with LS3MIP, it was decided to launch the ESMSnowMIP simulations after the main CMIP6 activities. This, however, has the disadvantage that ESM-SnowMIP global simulation results will not be available for analysis in time for the sixth IPCC assessment report.

For these global land-only and coupled simulations, the request for output variables is identical to the LS3MIP data request (https://www.earthsystemcog.org/projects/wip/ CMIP6DataRequest, last access: 3 December 2018) for the respective reference simulations indicated in Table 2, and the model set-up will be very similar, as described in the preceding sections of this paper. This further keeps the additional workload for the ESM-SnowMIP coupled simulations to a minimum.

The ESM-SnowMIP site simulation output is sufficiently small to be easily handled via an ftp server at one of the participating institutes (see the dedicated website at https: //www.geos.ed.ac.uk/ ressery/ESM-SnowMIP.html, last access: 3 December 2018). Gridded Northern Hemisphere SWE data are freely available from the National Snow and Ice Data Center (http://nsidc.org/data/NSIDC-0668, last access: 3 December 2018). Large-scale meteorological forcing (GSWP3) for the distributed simulations, also used in LS3MIP, will be made available via the ESGF at https: //esgf-node.llnl.gov/search/input4mips/ (last access: 3 December 2018). To optimize synergies with LS3MIP, ESMSnowMIP will seek endorsement by the WCRP Working Group on Coupled Modelling, which oversees CMIP. This will allow ESM-SnowMIP output to be handled via the Earth System Grid Federation (https://esgf.llnl.gov/, last access: 3 December 2018), i.e. the same infrastructures as the relevant CMIP6 simulations these simulations are to be compared with.

\section{Discussion}

\subsection{Expected outcome and impact of ESM-SnowMIP}

The parameterization of "cold" land surface processes has received varying degrees of attention by climate modelling groups. In the framework of CMIP6, there is now a specific type of numeric experiment specifically designed for evaluating the land surface components of the current-generation Earth system models. It is envisaged that these so-called LMIP exercises could become a central component of future
CMIP editions as part of the so-called DECK core experiments (Eyring et al., 2016), along with separate evaluations of the atmospheric and ocean components.

The specific effort aiming at evaluating and improving the representation of snow in ESMs and in more specific dedicated snow models relates to this broader context. It is hoped that ESM-SnowMIP, in conjunction with LS3MIP, will provide a clear determination of the current state of the art of snow modelling in the different participating communities and will spur knowledge transfer between these partially disjointed scientific communities. Snow modules in currentgeneration ESMs show a wide spread in their degree of complexity. We expect that ESM groups who have not devoted particular effort to evaluating and improving their snow modules in the past will be able to benefit from a clear strategy for priorities of first-order snow module enhancements identified within ESM-SnowMIP. For groups that have already put substantial effort into testing and continuously adapting their ESM snow modules or specific snow models, ESMSnowMIP will be an opportunity to assess past and determine future priorities for model enhancement.

The intended assessment of snow-related feedbacks on interannual and longer timescales, such as a multi-model evaluation of the snow shortwave radiative effect, will hopefully help better constrain the global climate response to anthropogenic forcing and better understand regional responses, including the amplification of global warming at high northern latitudes.

\subsection{Possible actions for future follow-up projects}

Recent work on tundra snow (Domine et al., 2016) has highlighted the importance and specificity of snow metamorphic processes under very cold conditions, specifically in the presence of strong vertical temperature gradients. While wind compaction in the absence of shelter by higher vegetation can increase snow density (Sturm et al., 2001) and hence snow conductivity, depth hoar formation induced by strong vertical temperature gradients within the snowpack (Derksen et al., 2009, 2014) can substantially reduce the conductivity (Domine et al., 2016). In ESM-SnowMIP, an effort will be made to include snow observation sites from tundra environments in the near future (e.g. Boike et al., 2018). However, it is clear that in future extensions of ESM-SnowMIP, snow on sea ice and on the polar ice sheets should also become a focus of attention. The physical properties of snow on sea ice are linked to low accumulation rates and strong vertical temperature gradients due to bottom heat flux, its spatial heterogeneity, its peculiar evolution in summer leading to melt ponds on sea ice due to inhibited drainage of meltwater, and the presence of salt. These are specificities that are, to our knowledge, often not taken into account in Earth system models; however, snow on sea ice obviously concerns the sea ice module of the coupled models and thus a slightly different community than that mobilized in this first version of ESM- 
SnowMIP. Assessments of snow on sea ice usually focus on, and are usually limited to, snow mass and height (BlanchardWrigglesworth et al., 2015; e.g. Hezel et al., 2012). However, an extension of the ESM-SnowMIP approach based on combined small- and large-scale evaluation of snow models will necessarily be conditioned by the availability of high-quality observations. In this context, the MOSAIC international Arctic drift expedition (https://www.mosaic-expedition.org/, last access: 3 December 2018) is projected to provide valuable new observations.

A further obvious follow-up of ESM-SnowMIP could tackle snow in extreme polar environments such as Dome C on the East Antarctic Plateau or the Greenland Summit; longterm meteorological observations have already been used at these locations for testing stand-alone snow models (Carmagnola et al., 2013; Libois et al., 2015). Perennial snow cover evolving under such extreme conditions would substantially broaden the range of snow types evaluated within our framework. This would provide stringent tests for snow models designed to simulate snow types that are extreme but far from rare, as the interior regions of the continental polar ice sheets make up an essential part of the perennial cryosphere.

ESM-SnowMIP combines model evaluation at local and global scales. While snow, and particularly the timing and intensity of its melt season, does have important effects on basin-scale hydrology (Barnhart et al., 2016; e.g. Berghuijs et al., 2014; Fyfe et al., 2017), basin-scale processes exert a less dominant control on snow as such in terms of physical properties. Therefore, intermediate scales, such as those addressed in the Rhône-Aggregation Land Surface Scheme Intercomparison Project (Boone et al., 2004), are bridged in the current phase of ESM-SnowMIP. However, terrain configuration and vegetation distribution (that is, geographical characteristics at intermediate (basin) scales) have an obvious and important effect on the snow cover, in particular on snow cover fraction. In the current phase of ESM-SnowMIP, such links are implicitly addressed through the assessment of snow cover fraction in the prescribed SWE experiment SWELSM. In future phases, basin-scale properties, processes, and characteristics might be addressed more explicitly. A further aspect involving unresolved scales that could be tackled in future extensions of ESM-SnowMIP is the high spatial variability of impurities deposited on snow surfaces, given the known strong impact of this deposition on snow albedo (Flanner et al., 2007) and model errors that can be induced by not taking this effect into account (e.g. Clark et al., 2015).

Data availability. Site forcing data are available through https: //www.geos.ed.ac.uk/ ressery/ESM-SnowMIP/netcdf.zip (last access: 7 December 2018). The Weissfluhjoch data are accessible via https://doi.org/10.16904/16 (WSL, 2017). A paper describing the site-scale input data is currently in preparation.
Author contributions. GK, CD, RE, MF, SH, MC, AH, and HR initially designed the experimental design. GK, CD, RE, CBM, LM and LW led the initial writing of different parts of the paper. RE and CBM led the analysis of the site simulations. All other participants contributed to the final experimental design, the site simulations and the projected analysis strategy.

Competing interests. The authors declare that they have no conflict of interest.

Acknowledgements. This project was supported by the World Climate Research Programme's Climate and Cryosphere (CliC) core project. We acknowledge the World Climate Research Programme's Working Group on Coupled Modelling, which is responsible for CMIP. For CMIP the U.S. Department of Energy's Program for Climate Model Diagnosis and Intercomparison provides coordinating support and led the development of software infrastructure in partnership with the Global Organization for Earth System Science Portals. Analysis of ESM-SnowMIP reference site simulations is supported by NERC grant NE/P011926/1. Gerhard Krinner, Chris Derksen, and Richard Essery acknowledge support by the ESA in the framework of the ESA CCI snow project. Simulations by the SWAP model were supported by the Russian Science Foundation (grant 16-17-10039; Yeugeniy M. Gusev is the recipient). Simulations by the SPONSOR model were supported by the Russian Foundation for Basic Research (grant 18-05-60216; Vladimir A. Semenov is the recipient). The work of Gabriele Arduini leading to this paper was funded through the APPLICATE project. APPLICATE has received funding from the European Union's Horizon 2020 research and innovation programme under grant agreement 727862. Nander Wever was supported by the Swiss National Science Foundation (project 200021E-160667). IGE and CNRM/CEN are part of LabEX OSUG@2020 (ANR10 LABX56). Stefan Hagemann and Tobias Stacke were partially supported by funding from the European Union within the Horizon 2020 project CRESCENDO (grant no. 641816). Hyungjun Kim acknowledges support by a Grant-in-Aid for Specially Promoted Research 16H06291 from JSPS. Alex Hall was supported by the U.S. National Science Foundation under grant number 1543268 "Reducing Uncertainty Surrounding Climate Change Using Emergent Constraints". The authors sincerely thank Eric BrunBarrière for his leading role during the initial planning stages of ESM-SnowMIP.

Edited by: Jeremy Fyke

Reviewed by: two anonymous referees

\section{References}

Balsamo, G., Albergel, C., Beljaars, A., Boussetta, S., Brun, E., Cloke, H., Dee, D., Dutra, E., Muñoz-Sabater, J., Pappenberger, F., de Rosnay, P., Stockdale, T., and Vitart, F.: ERAInterim/Land: a global land surface reanalysis data set, Hydrol. Earth Syst. Sci., 19, 389-407, https://doi.org/10.5194/hess-19389-2015, 2015. 
Barnett, T. P., Adam, J. C., and Lettenmaier, D. P.: Potential impacts of a warming climate on water availability in snow-dominated regions, Nature, 438, 303-309, https://doi.org/10.1038/nature04141, 2005.

Barnhart, T. B., Molotch, N. P., Livneh, B., Harpold, A. A., Knowles, J. F., and Schneider, D.: Snowmelt rate dictates streamflow, Geophys. Res. Lett., 43, 8006-8016, https://doi.org/10.1002/2016GL069690, 2016.

Bartlett, P. A., MacKay, M. D., and Verseghy, D. L.: Modified snow algorithms in the Canadian Land Surface Scheme: Model runs and sensitivity analysis at three boreal forest stands, Atmos.Ocean, 44, 207-222, https://doi.org/10.3137/ao.440301, 2006.

Berghuijs, W. R., Woods, R. A., and Hrachowitz, M.: A precipitation shift from snow towards rain leads to a decrease in streamflow, Nat. Clim. Change, 4, 583-586, https://doi.org/10.1038/nclimate2246, 2014.

Best, M. J., Pryor, M., Clark, D. B., Rooney, G. G., Essery, R. L. H., Ménard, C. B., Edwards, J. M., Hendry, M. A., Porson, A., Gedney, N., Mercado, L. M., Sitch, S., Blyth, E., Boucher, O., Cox, P. M., Grimmond, C. S. B., and Harding, R. J.: The Joint UK Land Environment Simulator (JULES), model description Part 1: Energy and water fluxes, Geosci. Model Dev., 4, 677-699, https://doi.org/10.5194/gmd-4-677-2011, 2011.

Betts, A. K., Desjardins, R., Worth, D., Wang, S., and Li, J.: Coupling of winter climate transitions to snow and clouds over the Prairies, J. Geophys. Res., 119, 1118-1139, https://doi.org/10.1002/2013JD021168, 2014.

Biskaborn, B. K., Lanckman, J.-P., Lantuit, H., Elger, K., Streletskiy, D. A., Cable, W. L., and Romanovsky, V. E.: The new database of the Global Terrestrial Network for Permafrost (GTN-P), Earth Syst. Sci. Data, 7, 245-259, https://doi.org/10.5194/essd-7-245-2015, 2015.

Blanchard-Wrigglesworth, E., Farrell, S. L., Newman, T., and Bitz, C. M.: Snow cover on Arctic sea ice in observations and an Earth System Model, Geophys. Res. Lett., 42, 10342-10348, https://doi.org/10.1002/2015GL066049, 2015.

Boike, J., Juszak, I., Lange, S., Chadburn, S., Burke, E., Overduin, P. P., Roth, K., Ippisch, O., Bornemann, N., Stern, L., Gouttevin, I., Hauber, E., and Westermann, S.: A 20-year record (19982017) of permafrost, active layer and meteorological conditions at a high Arctic permafrost research site (Bayelva, Spitsbergen), Earth Syst. Sci. Data, 10, 355-390, https://doi.org/10.5194/essd10-355-2018, 2018.

Bonan, G. B., Levis, S., Kergoat, L., and Oleson, K. W.: Landscapes as patches of plant functional types: An integrating concept for climate and ecosystem models, Global Biogeochem. Cy., 16, 51-5-23, https://doi.org/10.1029/2000GB001360, 2002.

Bontemps, S., Herold, M., Kooistra, L., van Groenestijn, A., Hartley, A., Arino, O., Moreau, I., and Defourny, P.: Revisiting land cover observation to address the needs of the climate modeling community, Biogeosciences, 9, 2145-2157, https://doi.org/10.5194/bg-9-2145-2012, 2012

Bony, S., Colman, R., Kattsov, V. M., Allan, R. P., Bretherton, C. S., Dufresne, J. L., Hall, A., Hallegatte, S., Holland, M. M., Ingram, W., Randall, D. A., Soden, B. J., Tselioudis, G., and Webb, M. J.: How well do we understand and evaluate climate change feedback processes?, J. Climate, 19, 3445-3482, https://doi.org/10.1175/JCLI3819.1, 2006.
Boone, A. and Etchevers, P.: An Intercomparison of Three Snow Schemes of Varying Complexity Coupled to the Same Land Surface Model: Local-Scale Evaluation at an Alpine Site, J. Hydrometeorol., 2, 374-394, https://doi.org/10.1175/15257541(2001)002<0374:AIOTSS>2.0.CO;2, 2001.

Boone, A., Habets, F., Noilhan, J., Clark, D., Dirmeyer, P., Fox, S., Gusev, Y., Haddeland, I., Koster, R., Lohmann, D., Mahanama, S., Mitchell, K., Nasonova, O., Niu, G.-Y., Pitman, A., Polcher, J., Shmakin, A. B., Tanaka, K., van den Hurk, B., Vérant, S., Verseghy, D., Viterbo, P., and Yang, Z.-L.: The RhôneAggregation Land Surface Scheme intercomparison project: An overview, J. Climate, 17, 187-208, https://doi.org/10.1175/15200442(2004)017<0187:TRLSSI>2.0.CO;2, 2004.

Bowling, L. C., Lettenmaier, D. P., Nijssen, B., Graham, L. P., Clark, D. B., El Maayar, M., Essery, R., Goers, S., Gusev, Y. M., Habets, F., Van Den Hurk, B., Jin, J., Kahan, D., Lohmann, D., Ma, X., Mahanama, S., Mocko, D., Nasonova, O., Niu, G. Y., Samuelsson, P., Shmakin, A. B., Takata, K., Verseghy, D., Viterbo, P., Xia, Y., Xue, Y., and Yang, Z. L.: Simulation of high-latitude hydrological processes in the TorneKalix basin: PILPS Phase 2(e) 1: Experiment description and summary intercomparisons, Global Planet. Change, 38, 1-30, https://doi.org/10.1016/S0921-8181(03)00003-1, 2003.

Braun, F. J. and Schädler, G.: Comparison of Soil Hydraulic Parameterizations for Mesoscale Meteorological Models, J. Appl. Meteorol., 44, 1116-1132, https://doi.org/10.1175/JAM2259.1, 2005.

Brown, R. D. and Mote, P. W.: The response of Northern Hemisphere snow cover to a changing climate, J. Climate, 22, 2124 2145, https://doi.org/10.1175/2008JCLI2665.1, 2009.

Brun, E., Vionnet, V., Boone, A., Decharme, B., Peings, Y., Valette, R., Karbou, F., and Morin, S.: Simulation of Northern Eurasian Local Snow Depth, Mass, and Density Using a Detailed Snowpack Model and Meteorological Reanalyses, J. Hydrometeorol. 14, 203-219, https://doi.org/10.1175/JHM-D-12-012.1, 2013.

Brutel-Vuilmet, C., Ménégoz, M., and Krinner, G.: An analysis of present and future seasonal Northern Hemisphere land snow cover simulated by CMIP5 coupled climate models, The Cryosphere, 7, 67-80, https://doi.org/10.5194/tc-7-67-2013, 2013.

Carmagnola, C. M., Domine, F., Dumont, M., Wright, P., Strellis, B., Bergin, M., Dibb, J., Picard, G., Libois, Q., Arnaud, L., and Morin, S.: Snow spectral albedo at Summit, Greenland: measurements and numerical simulations based on physical and chemical properties of the snowpack, The Cryosphere, 7, 1139-1160, https://doi.org/10.5194/tc-7-1139-2013, 2013.

Chapin III, F. S., Sturm, M., Serreze, M. C., Mcfadden, J. P., Key, J. R., Lloyd, A. H., Mcguire, A. D., Rupp, T. S., and Lynch, A. H.: Role of Land-Surface Changes in Arctic Summer Warming, Science, 310, 657-660, 2005.

Clark, M. P., Nijssen, B., Lundquist, J. D., Kavetski, D., Rupp, D. E., Woods, R. A., Freer, J. E., Gutmann, E. D., Wood, A. W., Gochis, D. J., Rasmussen, R. M., Tarboton, D. G., Mahat, V., Flerchinger, G. N., and Marks, D. G.: A unified approach for process-based hydrologic modeling: 2. Model implementation and case studies, Water Resour. Res., 51, 2515-2542, https://doi.org/10.1002/2015WR017200, 2015.

Cohen, J. L., Furtado, J. C., Barlow, M. A., Alexeev, V. A., and Cherry, J. E.: Arctic warming, increasing snow cover and 
widespread boreal winter cooling, Environ. Res. Lett., 7, 011004 , https://doi.org/10.1088/1748-9326/7/1/014007, 2012.

Collins, M., Knutti, R., Arblaster, J., Dufresne, J.-L., Fichefet, T., Friedlingstein, P., Gao, X., Gutowski, W. J., Johns, T., Krinner, G., Shongwe, M., Tebaldi, C., Weaver, A. J., and Wehner, M.: Long-term Climate Change: Projections, Commitments and Irreversibility, in: Climate Change 2013: The Physical Science Basis, Contribution of Working Group I to the Fifth Assessment Report of the Intergovernmental Panel on Climate Change, 10291136., 2013.

Cook, B. I., Bonan, G. B., Levis, S., and Epstein, H. E.: The thermoinsulation effect of snow cover within a climate model, Clim. Dynam., 31, 107-124, https://doi.org/10.1007/s00382007-0341-y, 2008.

Cox, P. M., Betts, R. A., Bunton, C. B., Essery, R. L. H., Rowntree, P. R., and Smith, J.: The impact of new land surface physics on the GCM simulation of climate and climate sensitivity, Clim. Dynam., 15, 183-203, https://doi.org/10.1007/s003820050276, 1999.

Cuntz, M. and Haverd, V.: Physically Accurate Soil Freeze-Thaw Processes in a Global Land Surface Scheme, J. Adv. Model. Earth Sy., 10, 54-77, https://doi.org/10.1002/2017MS001100, 2018.

Dai, Y., Zeng, X., Dickinson, R. E., Baker, I., Bonan, G. B., Bosilovich, M. G., Denning, A. S., Dirmeyer, P. A., Houser, P. R., Niu, G., Oleson, K. W., Schlosser, C. A., and Yang, Z. L.: The common land model, B. Am. Meteorol. Soc., 84, 1013-1023, https://doi.org/10.1175/BAMS-84-8-1013, 2003.

Decharme, B., Brun, E., Boone, A., Delire, C., Le Moigne, P., and Morin, S.: Impacts of snow and organic soils parameterization on northern Eurasian soil temperature profiles simulated by the ISBA land surface model, The Cryosphere, 10, 853-877, https://doi.org/10.5194/tc-10-853-2016, 2016.

Derksen, C. and Brown, R.: Spring snow cover extent reductions in the 2008-2012 period exceeding climate model projections, Geophys. Res. Lett., 39, 1-6, https://doi.org/10.1029/2012GL053387, 2012.

Derksen, C., Silis, A., Sturm, M., Holmgren, J., Liston, G. E., Huntington, H., and Solie, D.: Northwest Territories and Nunavut Snow Characteristics from a Subarctic Traverse: Implications for Passive Microwave Remote Sensing, J. Hydrometeorol., 10, 448-463, https://doi.org/10.1175/2008JHM1074.1, 2009.

Derksen, C., Lemmetyinen, J., Toose, P., Silis, A., Pulliainen, J., and Sturm, M.: Physical properties of arctic versus subarctic snow: Implications for high latitude passive microwave snow water equivalent retrievals, J. Geophys. Res., 119, 7254-7270, https://doi.org/10.1002/2013JD021264, 2014.

Déry, S. J. and Brown, R. D.: Recent Northern Hemisphere snow cover extent trends and implications for the snow-albedo feedback, Geophys. Res. Lett., 34, 2-7, https://doi.org/10.1029/2007GL031474, 2007.

Dirmeyer, P. A., Kumar, S., Fennessy, M. J., Altshuler, E. L., Delsole, T., Guo, Z., Cash, B. A., and Straus, D.: Model estimates of land-driven predictability in a changing climate from CCSM4, J. Climate, 26, 8495-8512, https://doi.org/10.1175/JCLI-D-13$00029.1,2013$.

Domine, F., Barrere, M., and Sarrazin, D.: Seasonal evolution of the effective thermal conductivity of the snow and the soil in high
Arctic herb tundra at Bylot Island, Canada, The Cryosphere, 10, 2573-2588, https://doi.org/10.5194/tc-10-2573-2016, 2016.

Dutra, E., Balsamo, G., Viterbo, P., Miranda, P. M. A., Beljaars, A., Schär, C., and Elder, K.: An Improved Snow Scheme for the ECMWF Land Surface Model: Description and Offline Validation, J. Hydrometeorol., 11, 899-916, https://doi.org/10.1175/2010JHM1249.1, 2010.

Dutra, E., Viterbo, P., Miranda, P. M. A., and Balsamo, G.: Complexity of Snow Schemes in a Climate Model and Its Impact on Surface Energy and Hydrology, J. Hydrometeorol., 13, 521-538, https://doi.org/10.1175/JHM-D-11-072.1, 2012.

Ekici, A., Beer, C., Hagemann, S., Boike, J., Langer, M., and Hauck, C.: Simulating high-latitude permafrost regions by the JSBACH terrestrial ecosystem model, Geosci. Model Dev., 7, 631-647, https://doi.org/10.5194/gmd-7-631-2014, 2014.

ESA: Land Cover CCI Product User Guide Version 2, CCILC-PUGv2, available at: http://maps.elie.ucl.ac.be/CCI/viewer/ download/ESACCI-LC-Ph2-PUGv2_2.0.pdf (last access: 4 December 2018), 2017.

Essery, R.: Large-scale simulations of snow albedo masking by forests, Geophys. Res. Lett., 40, 5521-5525, https://doi.org/10.1002/grl.51008, 2013.

Essery, R.: A factorial snowpack model (FSM 1.0), Geosci. Model Dev., 8, 3867-3876, https://doi.org/10.5194/gmd-8-3867-2015, 2015.

Essery, R., Rutter, N., Pomeroy, J., Baxter, R., Stähli, M., Gustafsson, D., Barr, A., Bartlett, P., and Elder, K.: SNOWMIP2: An Evaluation of Forest Snow Process Simulations, B. Am. Meteorol. Soc., 90, 1120-1135, https://doi.org/10.1175/2009BAMS2629.1, 2009.

Essery, R., Morin, S., Lejeune, Y., and B Ménard, C.: A comparison of 1701 snow models using observations from an alpine site, Adv. Water Resour., 55, 131-148, https://doi.org/10.1016/j.advwatres.2012.07.013, 2013.

Essery, R., Kontu, A., Lemmetyinen, J., Dumont, M., and Ménard, C. B.: A 7-year dataset for driving and evaluating snow models at an Arctic site (Sodankylä, Finland), Geosci. Instrum. Method. Data Syst., 5, 219-227, https://doi.org/10.5194/gi-5-219-2016, 2016.

Etchevers, P., Martin, E., Brown, R., Fierz, C., Lejeune, Y., Bazile, E., Boone, A., Dai, Y.-J., Essery, R. L. H., Fernandez, A., Gusev, Y., Jordan, R., Koren, V., Kowalczyk, E., Nasonova, O., Pyles, R. D., Schlosser, A., Shmakin, a B., Smirnova, T. G., Strosser, U., Verseghy, D., Yamazaki, T., Yang, Z.-L., Nasonova, N. O., and Strasser, U.: Validation of the surface energy budget simulated by several snow models, Ann. Glaciol., 38, 150-158, https://doi.org/10.3189/172756404781814825, 2004.

Eyring, V., Bony, S., Meehl, G. A., Senior, C. A., Stevens, B., Stouffer, R. J., and Taylor, K. E.: Overview of the Coupled Model Intercomparison Project Phase 6 (CMIP6) experimental design and organization, Geosci. Model Dev., 9, 1937-1958, https://doi.org/10.5194/gmd-9-1937-2016, 2016.

Flanner, M. G., Zender, C. S., Randerson, J. T., and Rasch, P. J.: Present-day climate forcing and response from black carbon in snow, J. Geophys. Res.-Atmos., 112, 1-17, https://doi.org/10.1029/2006JD008003, 2007.

Flanner, M. G., Shell, K. M., Barlage, M., Perovich, D. K., and Tschudi, M. A.: Radiative forcing and albedo feedback from the 
Northern Hemisphere cryosphere between 1979 and 2008, Nat. Geosci., 4, 151-155, https://doi.org/10.1038/ngeo1062, 2011.

Fritz, S., See, L., McCallum, I., Schill, C., Obersteiner, M., Van Der Velde, M., Boettcher, H., Havlík, P., and Achard, F.: Highlighting continued uncertainty in global land cover maps for the user community, Environ. Res. Lett., 6, 044005, https://doi.org/10.1088/1748-9326/6/4/044005, 2011.

Fyfe, J. C., Derksen, C., Mudryk, L., Flato, G. M., Santer, B. D., Swart, N. C., Molotch, N. P., Zhang, X., Wan, H., Arora, V. K., Scinocca, J., and Jiao, Y.: Large near-Term projected snowpack loss over the western United States, Nat. Commun., 8, 1-7, https://doi.org/10.1038/ncomms14996, 2017.

Gates, W. L.: AMIP: The Atmospheric Model Intercomparison Project, B. Am. Meteorol. Soc., 73, 1962-1970, https://doi.org/10.1175/15200477(1992)073<1962:ATAMIP>2.0.CO;2, 1992.

Gouttevin, I., Menegoz, M., Dominé, F., Krinner, G., Koven, C., Ciais, P., Tarnocai, C., and Boike, J.: How the insulating properties of snow affect soil carbon distribution in the continental pan-Arctic area, J. Geophys. Res.-Biogeo., 117, 1-11, https://doi.org/10.1029/2011JG001916, 2012.

Gouttevin, I., Langer, M., Löwe, H., Boike, J., Proksch, M., and Schneebeli, M.: Observation and modelling of snow at a polygonal tundra permafrost site: spatial variability and thermal implications, The Cryosphere, 12, 3693-3717, https://doi.org/10.5194/tc-12-3693-2018, 2018.

Groffman, P. M., Driscoll, C. T., Fahey, T. J., and Al, E.: Colder soils in a warmer world: A snowmanipulation study in a northern hardwood forest ecosystem, Biogeochemistry, 56, 135-150, 2001.

Gusev, Y. M. and Nasonova, O. N.: The simulation of heat and water exchange in the boreal spruce forest by the land-surf ace model SWAP, J. Hydrol., 280, 162-191, https://doi.org/10.1016/S00221694(03)00221-X, 2003.

Harding, R. J. and Pomeroy, J. W.: The energy balance of the winter boreal landscape, J. Climate, 9, 2778-2787, https://doi.org/10.1175/15200442(1996)009<2778:TEBOTW>2.0.CO;2, 1996.

Hartley, A. J., MacBean, N., Georgievski, G., and Bontemps, S.: Uncertainty in plant functional type distributions and its impact on land surface models, Remote Sens. Environ., 20, 71-89, https://doi.org/10.1016/j.rse.2017.07.037, 2017.

Herold, M., Mayaux, P., Woodcock, C. E., Baccini, A., and Schmullius, C.: Some challenges in global land cover mapping: An assessment of agreement and accuracy in existing $1 \mathrm{~km}$ datasets, Remote Sens. Environ., 112, 2538-2556, https://doi.org/10.1016/j.rse.2007.11.013, 2008.

Hezel, P. J., Zhang, X., Bitz, C. M., Kelly, B. P., and Massonnet, F.: Projected decline in spring snow depth on Arctic sea ice caused by progressively later autumn open ocean freeze-up this century, Geophys. Res. Lett., 39, 6-11, https://doi.org/10.1029/2012GL052794, 2012.

Kim, H.: Global Soil Wetness Project Phase 3 Atmospheric Boundary Conditions (Experiment 1) [Data set], Data Integration and Analysis System (DIAS), https://doi.org/10.20783/DIAS.501, 2017

Koven, C. D., Riley, W. J., and Stern, A.: Analysis of permafrost thermal dynamics and response to climate change in the CMIP5 earth system models, J. Climate, 26, 1877-1900, https://doi.org/10.1175/JCLI-D-12-00228.1, 2013.

Lafaysse, M., Cluzet, B., Dumont, M., Lejeune, Y., Vionnet, V., and Morin, S.: A multiphysical ensemble system of numerical snow modelling, The Cryosphere, 11, 1173-1198, https://doi.org/10.5194/tc-11-1173-2017, 2017.

Landry, C. C., Buck, K. A., Raleigh, M. S., and Clark, M. P.: Mountain system monitoring at Senator Beck Basin, San Juan Mountains, Colorado: A new integrative data source to develop and evaluate models of snow and hydrologic processes, Water Resour. Res., 50, 1773-1788, https://doi.org/10.1002/2013WR013711, 2014.

Lawrence, D. M., Slater, A. G., Romanovsky, V. E., and Nicolsky, D. J.: Sensitivity of a model projection of near-surface permafrost degradation to soil column depth and representation of soil organic matter, J. Geophys. Res.-Earth, 113, F02011, https://doi.org/10.1029/2007JF000883, 2008.

Lawrence, D. M., Fisher, R. A., Koven, C. D., Oleson, K. W., Swenson, S. C., Bonan, G., Collier, N., Ghimire, B., van Kampenhout, L., Kennedy, D., Kluzek, E., Lawrence, P. J., Li, F., Li, H., Lombardozzi, D., Riley, W. J., Sacks, W. J., Shi, M., Vertenstein, M., Wieder, W. R., Xu, C., Ali, A. A., Badger, A. M., Bisht, G., Brunke, M. A., Burns, S. P., Buzan, J., Clark, M., Craig, A., Dahlin, K., Drewniak, B., Fisher, J. B., Flanner, M., Fox, A. M., Gentine, P., Hoffman, F., Keppel-Aleks, G., Knox, R., Kumar, S., Lenaerts, J., Leung, L. R., Lipscomb, W. H., Lu, Y., Pandey, A., Pelletier, J. D., Perket, J., Randerson, J. T., Ricciuto, D. M., Sanderson, B. M., Slater, A., Subin, Z. M., Tang, J., Thomas, R. Q., Val Martin, M., and Zeng, X.: The Community Land Model version 5: Description of new features, benchmarking, and impact of forcing uncertainty. J. Adv. Model. Earth Sy., submitted, 2018.

Lehning, M., Bartelt, P., Brown, B., Russi, T., Stöckli, U., and Zimmerli, M.: SNOWPACK model calculations for avalanche warning based upon a new network of weather and snow stations, Cold Reg. Sci. Technol., 30, 145-157, https://doi.org/10.1016/S0165-232X(99)00022-1, 1999.

Lejeune, Y., Dumont, M., Panel, J.-M., Lafaysse, M., Lapalus, P., Le Gac, E., Lesaffre, B., and Morin, S.: 57 years (1960-2017) of snow and meteorological observations from a mid-altitude mountain site (Col de Porte, France, $1325 \mathrm{~m}$ alt.), Earth Syst. Sci. Data Discuss., https://doi.org/10.5194/essd-2018-84, in review, 2018.

Lewis, P., Guanter, L., Lopez Saldana, G., Muller, J. P., Watson, G., Shane, N., Kennedy, T., Fisher, J., Domenech, C., Preusker, R., North, P., Heckel, A., Danne, O., Kramer, U., Zuhlke, M., Fomferra, N., Brockmann, C., and Schaaf, C.: The ESA globAlbedo project: Algorithm, in International Geoscience and Remote Sensing Symposium (IGARSS), 5745-5748, 2012.

Libois, Q., Picard, G., Arnaud, L., Dumont, M., Lafaysse, M., Morin, S., and Lefebvre, E.: Summertime evolution of snow specific surface area close to the surface on the Antarctic Plateau, The Cryosphere, 9, 2383-2398, https://doi.org/10.5194/tc-92383-2015, 2015.

Loranty, M. M., Berner, L. T., Goetz, S. J., Jin, Y., and Randerson, J. T.: Vegetation controls on northern high latitude snow-albedo feedback: Observations and CMIP5 model simulations, Glob. Change Biol., 20, 594-606, https://doi.org/10.1111/gcb.12391, 2014. 
Magnusson, J., Wever, N., Essery, R., Helbig, N., Winstral, A., and Jonas, T.: Evaluating snow models with varying process representations for hydrological applications, Water Resour. Res., 51, 2707-2723, https://doi.org/10.1002/2014WR016498, 2015.

Marke, T., Mair, E., Förster, K., Hanzer, F., Garvelmann, J., Pohl, S., Warscher, M., and Strasser, U.: ESCIMO.spread (v2): parameterization of a spreadsheet-based energy balance snow model for inside-canopy conditions, Geosci. Model Dev., 9, 633-646, https://doi.org/10.5194/gmd-9-633-2016, 2016.

Melloh, R. A., Hardy, J. P., Bailey, R. N., and Hall, T. J.: An efficient snow albedo model for the open and sub-canopy, Hydrol. Process., 16, 3571-3584, https://doi.org/10.1002/hyp.1229, 2002.

Mote, P. W., Li, S., Lettenmaier, D. P., Xiao, M., and Engel, R.: Dramatic declines in snowpack in the western US, npj Clim. Atmos. Sci., 1, 2, https://doi.org/10.1038/s41612-018-0012-1, 2018.

Mudryk, L. R., Derksen, C., Kushner, P. J., and Brown, R.: Characterization of Northern Hemisphere snow water equivalent datasets, 1981-2010, J. Climate, 28, 8037-8051, https://doi.org/10.1175/JCLI-D-15-0229.1, 2015.

Mudryk, L. R., Kushner, P. J., Derksen, C., and Thackeray, C.: Snow cover response to temperature in observational and climate model ensembles, Geophys. Res. Lett., 44, 919-926, https://doi.org/10.1002/2016GL071789, 2017.

Nijssen, B., Bowling, L. C., Lettenmaier, D. P., Clark, D. B., Maayar, M. El, Essery, R., Goers, S., Gusev, Y. M., Habets, F., van den Hurk, B., Jin, J. M., Kahan, D., Lohmann, D., Ma, X. Y., Mahanama, S., Mocko, D., Nasonova, O., Niu, G. Y., Samuelsson, P., Schmakin, A. B., Takata, K., Verseghy, D., Viterbo, P., Xia, Y. L., Xue, Y. K., and Yang, Z. L.: Simulation of high latitude hydrological processes in the TorneKalix basin: PILPS phase 2(e) - 2: Comparison of model results with observations, Global Planet. Change, 38, 31-53, https://doi.org/10.1016/S0921-8181(03)00004-3, 2003.

Niwano, M., Aoki, T., Kuchiki, K., Hosaka, M., and Kodama, Y.: Snow Metamorphism and Albedo Process (SMAP) model for climate studies: Model validation using meteorological and snow impurity data measured at Sapporo, Japan, J. Geophys. Res.Earth, 117, 1-18, https://doi.org/10.1029/2011JF002239, 2012.

Niwano, M., Aoki, T., Kuchiki, K., Hosaka, M., Kodama, Y., Yamaguchi, S., Motoyoshi, H., and Iwata, Y.: Evaluation of updated physical snowpack model SMAP, Bull. Glaciol. Res., 32, 65-78, https://doi.org/10.5331/bgr.32.65, 2014.

Nolin, A. W. and Daly, C.: Mapping "At Risk" Snow in the Pacific Northwest, J. Hydrometeorol., 7, 1164-1171, https://doi.org/10.1175/JHM543.1, 2006.

Oleson, K. W., Dai, Y., Bonan, G., Dickinson, R., Dirmeyer, P., Hoffmann, F., Houser, P., Levis, S., Niu, G.-Y., Thornton, P., Vertenstein, M., Yang, Z.-L., and Zeng, X.: Technical Description of the Community Land Model (CLM), Boulder, CO, available at: http://opensky.ucar.edu/islandora/object/technotes: 393 (last access: 3 December 2018), 2004.

Palazzi, E., Filippi, L., and von Hardenberg, J.: Insights into elevation-dependent warming in the Tibetan Plateau-Himalayas from CMIP5 model simulations, Clim. Dynam., 48, 3991-4008, https://doi.org/10.1007/s00382-016-3316-z, 2017.

Park, H., Fedorov, A. N., Zheleznyak, M. N., Konstantinov, P. Y., and Walsh, J. E.: Effect of snow cover on pan-Arctic permafrost thermal regimes, Clim. Dynam., 44, 2873-2895, https://doi.org/10.1007/s00382-014-2356-5, 2015.
Pepin, N., Bradley, R. S., Diaz, H. F., Baraer, M., Caceres, E. B., Forsythe, N., Fowler, H., Greenwood, G., Hashmi, M. Z., Liu, X. D., Miller, J. R., Ning, L., Ohmura, A., Palazzi, E., Rangwala, I., Schöner, W., Severskiy, I., Shahgedanova, M., Wang, M. B., Williamson, S. N., and Yang, D. Q.: Elevation-dependent warming in mountain regions of the world, Nat. Clim. Change, 5, 424-430, https://doi.org/10.1038/nclimate2563, 2015.

Perket, J., Flanner, M. G., and Kay, J. E.: Diagnosing shortwave cryosphere radiative effect and its 21st century evolution in CESM, J. Geophys. Res., 119, 1356-1362, https://doi.org/10.1002/2013JD021139, 2014.

Pithan, F. and Mauritsen, T.: Arctic amplification dominated by temperature feedbacks in contemporary climate models, Nat Geosci., 7, 181-184, https://doi.org/10.1038/ngeo2071, 2014.

Pomeroy, J., Fang, X., and Ellis, C.: Sensitivity of snowmelt hydrology in Marmot Creek, Alberta, to forest cover disturbance, Hydrol. Process., 26, 1891-1904, https://doi.org/10.1002/hyp.9248, 2012.

Pomeroy, J. W. and Jones, H. G.: Wind-Blown Snow: Sublimation, transport and changes to polar snow, in: Chemical exchange between atmosphere and polar snow, in: NATO ASI Series, edited by: Wolff, E. and Bales, R. C., Springer-Verlag, Berlin, Heidelberg, 43, 453-489, 1996.

Poulter, B., Ciais, P., Hodson, E., Lischke, H., Maignan, F., Plummer, S., and Zimmermann, N. E.: Plant functional type mapping for earth system models, Geosci. Model Dev., 4, 993-1010, https://doi.org/10.5194/gmd-4-993-2011, 2011.

Poulter, B., MacBean, N., Hartley, A., Khlystova, I., Arino, O., Betts, R., Bontemps, S., Boettcher, M., Brockmann, C., Defourny, P., Hagemann, S., Herold, M., Kirches, G., Lamarche, C., Lederer, D., Ottlé, C., Peters, M., and Peylin, P.: Plant functional type classification for earth system models: results from the European Space Agency's Land Cover Climate Change Initiative, Geosci. Model Dev., 8, 2315-2328, https://doi.org/10.5194/gmd8-2315-2015, 2015.

Pulliainen, J., Aurela, M., Laurila, T., Aalto, T., Takala, M., Salminen, M., Kulmala, M., Barr, A., Heimann, M., Lindroth, A., Laaksonen, A., Derksen, C., Mäkelä, A., Markkanen, T., Lemmetyinen, J., Susiluoto, J., Dengel, S., Mammarella, I., Tuovinen, J.-P., and Vesala, T.: Early snowmelt significantly enhances boreal springtime carbon uptake, P. Natl. Acad. Sci. USA, 114, 11081-11086, https://doi.org/10.1073/pnas.1707889114, 2017.

Qu, X. and Hall, A.: On the persistent spread in snow-albedo feedback, Clim. Dynam., 42, 69-81, https://doi.org/10.1007/s00382013-1774-0, 2014.

Räisänen, J.: Warmer climate: Less or more snow?, Clim. Dynam., 30, 307-319, https://doi.org/10.1007/s00382-007-0289-y, 2008.

Raleigh, M. S., Lundquist, J. D., and Clark, M. P.: Exploring the impact of forcing error characteristics on physically based snow simulations within a global sensitivity analysis framework, Hydrol. Earth Syst. Sci., 19, 3153-3179, https://doi.org/10.5194/hess-19-3153-2015, 2015.

Reba, M. L., Marks, D., Seyfried, M., Winstral, A., Kumar, M., and Flerchinger, G.: A long-term data set for hydrologic modeling in a snow-dominated mountain catchment, Water Resour. Res., 47, 1-7, https://doi.org/10.1029/2010WR010030, 2011.

Rienecker, M. M., Suarez, M. J., Gelaro, R., Todling, R., Bacmeister, J., Liu, E., Bosilovich, M. G., Schubert, S. D., Takacs, L., Kim, G. K., Bloom, S., Chen, J., Collins, D., Conaty, A., Da 
Silva, A., Gu, W., Joiner, J., Koster, R. D., Lucchesi, R., Molod, A., Owens, T., Pawson, S., Pegion, P., Redder, C. R., Reichle, R., Robertson, F. R., Ruddick, A. G., Sienkiewicz, M., and Woollen, J.: MERRA: NASA's modern-era retrospective analysis for research and applications, J. Climate, 24, 3624-3648, https://doi.org/10.1175/JCLI-D-11-00015.1, 2011.

Robinson, D. A., Hall, D. K., and Mote, T. L.: MEaSUREs Northern Hemisphere Terrestrial Snow Cover Extent Daily $25 \mathrm{~km}$ EASEGrid 2.0, Version 1, Boulder, Colorado USA, NASA National Snow and Ice Data Center Distributed Active Archive Center, https://doi.org/10.5067/MEASURES/CRYOSPHERE/nsidc0530.001, 2014.

Rodell, M., Houser, P. R., Jambor, U., Gottschalck, J., Mitchell, K., Meng, C.-J., Arsenault, K., Cosgrove, B., Radakovich, J., Bosilovich, M., Entin*, J. K., Walker, J. P., Lohmann, D., and Toll, D.: The Global Land Data Assimilation System, B. Am. Meteorol. Soc., 85, 381-394, https://doi.org/10.1175/BAMS-853-381, 2004.

Roeckner, E., Bäuml, G., Bonaventura, L., Brokopft, R., Esch, M., Giorgetta, M., Hagemann, S., Kirchner, I., Kornblueh, L., Manzini, E., Rhodin, A., Schlese, U., Schulzweida, U., and Tompkins, A.: The atmospheric general circulation model ECHAM5 -Part I?: Model description, MIP Rep., https://doi.org/10.1029/2010JD014036, 2003.

Rutter, N., Essery, R., Pomeroy, J., Altimir, N., Andreadis, K., Baker, I., Barr, A., Bartlett, P., Boone, A., Deng, H., Douville, H., Dutra, E., Elder, K., Ellis, C., Feng, X., Gelfan, A., Goodbody, A., Gusev, Y., Gustafsson, D., Hellström, R., Hirabayashi, Y., Hirota, T., Jonas, T., Koren, V., Kuragina, A., Lettenmaier, D., Li, W. P., Luce, C., Martin, E., Nasonova, O., Pumpanen, J., Pyles, R. D., Samuelsson, P., Sandells, M., Schädler, G., Shmakin, A., Smirnova, T. G., Stähli, M., Stöckli, R., Strasser, U., Su, H., Suzuki, K., Takata, K., Tanaka, K., Thompson, E., Vesala, T., Viterbo, P., Wiltshire, A., Xia, K., Xue, Y., and Yamazaki, T.: Evaluation of forest snow processes models (SnowMIP2), J. Geophys. Res.-Atmos., 114, D06111, https://doi.org/10.1029/2008JD011063, 2009.

Schaaf, C. B., Gao, F., Strahler, A. H., Lucht, W., Li, X., Tsang, T., Strugnell, N. C., Zhang, X., Jin, Y., Muller, J. P., Lewis, P., Barnsley, M., Hobson, P., Disney, M., Roberts, G., Dunderdale, M., Doll, C., D’Entremont, R. P., Hu, B., Liang, S., Privette, J. L., and Roy, D.: First operational BRDF, albedo nadir reflectance products from MODIS, Remote Sens. Environ., 83, 135-148, https://doi.org/10.1016/S0034-4257(02)00091-3, 2002.

Schlögl, S., Marty, C., Bavay, M., and Lehning, M.: Sensitivity of Alpine3D modeled snow cover to modifications in DEM resolution, station coverage and meteorological input quantities, Environ. Modell. Softw., 83, 387-396, https://doi.org/10.1016/j.envsoft.2016.02.017, 2016.

Schlögl, S., Lehning, M., Nishimura, K., Huwald, H., Cullen, N. J., and Mott, R.: How do Stability Corrections Perform in the Stable Boundary Layer Over Snow?, Bound.-Lay. Meteorol., 165, 161180, https://doi.org/10.1007/s10546-017-0262-1, 2017.

Schwaizer, G., Ripper, E., Nagler, T., Fernandes, R., Metsämäki, S., Solberg, R., Luojus, K., Derksen, C., Mudryk, L., and Brown, R.: ESA QA4EO SnowPEx - The Satellite Snow Product Intercomparison and Evaluation Experiment: Final Snow Product Intercomparison and Validation Report (Del. 13), ESA Contract No. 4000111278/14/I-LG (2014-2016), 123 pp., 2016.
Seneviratne, S. I., Lüthi, D., Litschi, M., and Schär, C.: Landatmosphere coupling and climate change in Europe, Nature, 443, 205-209, https://doi.org/10.1038/nature05095, 2006.

Seneviratne, S. I., Wilhelm, M., Stanelle, T., Van Den Hurk, B., Hagemann, S., Berg, A., Cheruy, F., Higgins, M. E., Meier, A., Brovkin, V., Claussen, M., Ducharne, A., Dufresne, J. L., Findell, K. L., Ghattas, J., Lawrence, D. M., Malyshev, S., Rummukainen, M., and Smith, B.: Impact of soil moistureclimate feedbacks on CMIP5 projections: First results from the GLACE-CMIP5 experiment, Geophys. Res. Lett., 40, 52125217, https://doi.org/10.1002/grl.50956, 2013.

Serreze, M. C. and Barry, R. G.: Processes and impacts of Arctic amplification: A research synthesis, Global Planet. Change, 77, 85-96, https://doi.org/10.1016/j.gloplacha.2011.03.004, 2011.

Singh, D., Flanner, M. G., and Perket, J.: The global land shortwave cryosphere radiative effect during the MODIS era, The Cryosphere, 9, 2057-2070, https://doi.org/10.5194/tc-9-20572015, 2015.

Slater, A. G., Schlosser, C. A., Desborough, C. E., Pitman, A. J., Henderson-Sellers, A., Robock, A., Vinnikov, K. Y., Entin, J., Mitchell, K., Chen, F., Boone, A., Etchevers, P., Habets, F., Noilhan, J., Braden, H., Cox, P. M., de Rosnay, P., Dickinson, R. E., Yang, Z.-L., Dai, Y.-J., Zeng, Q., Duan, Q., Koren, V., Schaake, S., Gedney, N., Gusev, Y. M., Nasonova, O. N., Kim, J., Kowalczyk, E. A., Shmakin, A. B., Smirnova, T. G., Verseghy, D., Wetzel, P., and Xue, Y.: The Representation of Snow in Land Surface Schemes: Results from PILPS 2(d), J. Hydrometeorol., 2, 7-25, https://doi.org/10.1175/15257541(2001)002<0007:TROSIL>2.0.CO;2, 2001.

Slater, A. G., Lawrence, D. M., and Koven, C. D.: Processlevel model evaluation: a snow and heat transfer metric, The Cryosphere, 11, 989-996, https://doi.org/10.5194/tc-11989-2017, 2017.

Smirnova, T. G., Brown, J. M., Benjamin, S. G., and Kenyon, J. S.: Modifications to the Rapid Update Cycle Land Surface Model (RUC LSM) Available in the Weather Research and Forecasting (WRF) Model, Mon. Weather Rev., 144, 1851-1865, https://doi.org/10.1175/MWR-D-15-0198.1, 2016.

Smith, D. M., Screen, J. A., Deser, C., Cohen, J., Fyfe, J. C., García-Serrano, J., Jung, T., Kattsov, V., Matei, D., Msadek, R., Peings, Y., Sigmond, M., Ukita, J., Yoon, J.-H., and Zhang, X.: The Polar Amplification Model Intercomparison Project (PAMIP) contribution to CMIP6: investigating the causes and consequences of polar amplification, Geosci. Model Dev. Discuss., https://doi.org/10.5194/gmd-2018-82, in review, 2018.

Sospedra-Alfonso, R., Merryfield, W. J., and Kharin, V. V.: Representation of Snow in the Canadian Seasonal to Interannual Prediction System. Part II: Potential Predictability and Hindcast Skill, J. Hydrometeorol., 17, 2511-2535, https://doi.org/10.1175/JHM-D-16-0027.1, 2016.

Sturm, M., Holmgren, J., König, M., and Morris, K.: The thermal conductivity of seasonal snow, J. Glaciol., 43, 26-41, 1997.

Sturm, M., McFadden, J. P., Liston, G. E., Stuart Chapin, F., Racine, C. H., and Holmgren, J.: Snow-shrub interactions in Arctic Tundra: A hypothesis with climatic implications, J. Climate, 14, 336-344, https://doi.org/10.1175/15200442(2001)014<0336:SSIIAT>2.0.CO;2, 2001. 
Sturm, M., Goldstein, M. A., and Parr, C.: Water and life from snow: A trillion dollar science question, Water Resour. Res., 53, 3534 3544, https://doi.org/10.1002/2017WR020840, 2017.

Takala, M., Luojus, K., Pulliainen, J., Derksen, C., Lemmetyinen, J., Kärnä, J. P., Koskinen, J., and Bojkov, B.: Estimating northern hemisphere snow water equivalent for climate research through assimilation of space-borne radiometer data and groundbased measurements, Remote Sens. Environ., 115, 3517-3529, https://doi.org/10.1016/j.rse.2011.08.014, 2011.

Tatebe, H., Ogura, T., Nitta, T., Komuro, Y., Ogochi, K., Takemura, T., Sudo, K., Sekiguchi, M., Abe, M., Saito, F., Chikira, M., Watanabe, S., Mori, M., Hirota, N., Kawatani, Y., Mochizuki, T., Yoshimura, K., Takata, K., O’ishi, R., Yamazaki, D., Suzuki, T., Kurogi, M., Kataoka, T., Watanabe, M., and Kimoto, M.: Description and basic evaluation of simulated mean state, internal variability, and climate sensitivity in MIROC6, Geosci. Model Dev. Discuss., https://doi.org/10.5194/gmd-2018-155, in review, 2018.

Thackeray, C. W., Fletcher, C. G., and Derksen, C.: Quantifying the skill of CMIP5 models in simulating seasonal albedo and snow cover evolution, J. Geophys. Res., 120, 5831-5849, https://doi.org/10.1002/2015JD023325, 2015.

Thackeray, C. W., Fletcher, C. G., Mudryk, L. R., and Derksen, C.: Quantifying the uncertainty in historical and future simulations of Northern Hemisphere spring snow cover, J. Climate, 29, 8647-8663, https://doi.org/10.1175/JCLI-D-16-0341.1, 2016.

Thackeray, C. W., Qu, X., and Hall, A.: Why do models produce spread in snow albedo feedback, Geophys. Res. Lett., 45, 62236231, 2018

Turkov, D. V. and Sokratov, V. S.: Calculating of snow cover characteristics on a plain territory using the model SPONSOR and data of reanalyses (by the example of Moscow region), Ice Snow, 56, 369-380, https://doi.org/10.15356/2076-6734-20163-369-380, 2016.

van den Hurk, B., Kim, H., Krinner, G., Seneviratne, S. I., Derksen, C., Oki, T., Douville, H., Colin, J., Ducharne, A., Cheruy, F., Viovy, N., Puma, M. J., Wada, Y., Li, W., Jia, B., Alessandri, A., Lawrence, D. M., Weedon, G. P., Ellis, R., Hagemann, S., Mao, J., Flanner, M. G., Zampieri, M., Materia, S., Law, R. M., and Sheffield, J.: LS3MIP (v1.0) contribution to CMIP6: the Land Surface, Snow and Soil moisture Model Intercomparison Project - aims, setup and expected outcome, Geosci. Model Dev., 9, 2809-2832, https://doi.org/10.5194/gmd-9-2809-2016, 2016. van Kampenhout, L., Lenaerts, J. T. M., Lipscomb, W. H., Sacks, W. J., Lawrence, D. M., Slater, A. G., and van den Broeke, M. R.: Improving the Representation of Polar Snow and Firn in the Community Earth System Model, J. Adv. Model. Earth Sy., 9, 2583-2600, https://doi.org/10.1002/2017MS000988, 2017.

Vavrus, S.: The role of terrestrial snow cover in the climate system, Clim. Dynam., 29, 73-88, https://doi.org/10.1007/s00382-0070226-0, 2007.

Vernekar, A. D., Zhou, J., and Shukla, J.: The Effect of Eurasian Snow Cover on the Indian Monsoon, J. Climate, 8, 248-266, 2010.

Vionnet, V., Brun, E., Morin, S., Boone, A., Faroux, S., Le Moigne, P., Martin, E., and Willemet, J.-M.: The detailed snowpack scheme Crocus and its implementation in SURFEX v7.2, Geosci. Model Dev., 5, 773-791, https://doi.org/10.5194/gmd-5773-2012, 2012.

Wang, L., Cole, J. N. S., Bartlett, P., Verseghy, D., Derksen, C., Brown, R., and Von Salzen, K.: Investigating the spread in surface albedo for snow-covered forests in CMIP5 models, J. Geophys. Res., 121, 1104-1119, https://doi.org/10.1002/2015JD023824, 2016.

Wang, T., Ottlé, C., Boone, A., Ciais, P., Brun, E., Morin, S., Krinner, G., Piao, S., and Peng, S.: Evaluation of an improved intermediate complexity snow scheme in the ORCHIDEE land surface model, J. Geophys. Res.-Atmos., 118, 6064-6079, https://doi.org/10.1002/jgrd.50395, 2013.

Wang, X. and Key, J. R.: Arctic surface, cloud, and radiation properties based on the AVHRR polar pathfinder dataset. Part II: Recent trends, J. Climate, 18, 2575-2593, https://doi.org/10.1175/JCLI3439.1, 2005.

WSL: Weissfluhjoch dataset for ESM-SnowMIP, https://doi.org/10.16904/16, 2017.

$\mathrm{Xu}, \mathrm{L}$. and Dirmeyer, P.: Snow-atmosphere coupling strength in a global atmospheric model, Geophys. Res. Lett., 38, 1-5, https://doi.org/10.1029/2011GL048049, 2011.

Zhang, T.: Influence of the seasonal snow cover on the ground thermal regime: An overview, Rev. Geophys., 43, RG4002, https://doi.org/10.1029/2004RG000157, 2005. 